\title{
Feeding the herds: Stable isotope analysis of animal diet and its implication for understanding social organisation in the Indus Civilisation, Northwest India
}

\author{
E. Lightfoot ${ }^{\mathrm{a}, *}$, P.J. Jones ${ }^{\mathrm{b}}$, P.P. Joglekar ${ }^{\mathrm{c}}$, M. Tames-Demauras ${ }^{\mathrm{d}}$, E. Smith ${ }^{\mathrm{d}}$, J. Muschinski ${ }^{\mathrm{e}}$, \\ V. Shinde ${ }^{c}$, R.N. Singh ${ }^{f}$, M.K. Jones ${ }^{d}$, T.C. O'Connell ${ }^{d}$, C.A. Petrie \\ ${ }^{a}$ McDonald Institute for Archaeological Research, University of Cambridge, UK \\ ${ }^{\mathrm{b}}$ Menzies Institute for Medical Research, College of Health and Medicine, University of Tasmania, Australia \\ ${ }^{\mathrm{c}}$ Deccan College, Pune, India \\ ${ }^{\mathrm{d}}$ Department of Archaeology, University of Cambridge, UK \\ ${ }^{\mathrm{e}}$ School of Anthropology and Museum Ethnography, University of Oxford, UK \\ ${ }^{\mathrm{f}}$ Department of AIHC and Archaeology, Banaras Hindu University, Varanasi, India
}

\section{A R T I C L E I N F O}

\section{Keywords:}

Carbon

Serial samples

Animal management

Sustainability

Adaptation

Resilience

\begin{abstract}
A B S T R A C T
The way that people manage their livestock tells us about their interactions with the landscape, particularly the nature of adaptation to specific environments, social organisation, resilience and long-term farming sustainability. Globally, there is considerable variation in how these practices are manifested, due to differences in water availability, levels of environmental diversity and aridity, and also the nature of cultural choices. South Asia's Indus Civilisation (c.3000-1500 BCE) provides an important opportunity for investigating how populations managed their animals, because the region shows considerable diversity in rainfall distribution, seasonality and intensity, which results in marked environmental variability that is susceptible to change over time. The latter is particularly significant when it comes to consideration of the impact of the $4.2 \mathrm{ka} \mathrm{BP}$ event and its relation to the deurbanisation of the Indus Civilisation.

This paper presents carbon isotope data from animal teeth from nine archaeological sites distributed across northwest India that are suitable for exploring how diverse practices were, and how animal management strategies changed through time. These data show clear differentiation in feeding practices between species, with cattle and water buffalo consuming very high proportions of $\mathrm{C}_{4}$ plants, while sheep and goat ate varying quantities of $\mathrm{C}_{3}$ and $\mathrm{C}_{4}$ plants. This pattern is generally consistent across sites and throughout different periods, suggesting that the strategy was adapted to a range of environmental conditions and settlements of different sizes. We suggest that humans controlled cow and water buffalo diets, and they were likely provided with fodder. In contrast, sheep and goats had a less controlled diet, and were presumably more likely to roam the landscape. These animal management strategies must have involved some separation of tasks, although it remains unclear if this was on a household, settlement or population level.
\end{abstract}

\section{Introduction}

The study of animal management strategies has a long history within archaeology. It provides important insights into understanding how past peoples lived their lives, interacted with the landscape and organised themselves to ensure that their subsistence requirements were satisfied. The extent to which such practices were maintained through time and across space can also provide insight into how adaptable they were to different environmental and social circumstances, their resilience to adversity and their long-term sustainability. The Indus Civilisation (c.3000-1500 BCE) has traditionally been viewed as having uniform and integrated material culture and cultural practices (e.g. Marshall, 1931). However, more recent research indicates that while there are broad similarities in some aspects of material culture throughout the Indus zone, variation is also evident (e.g. Chase et al., 2014; Meadow and Kenoyer, 1997; Parikh and Petrie, 2019; Petrie et al., 2017, 2018; Roux and Courty, 1998). This pattern extends to arable agriculture, with aspects of Indus cuisine, such as the

\footnotetext{
* Corresponding author at: McDonald Institute for Archaeological Research, University of Cambridge, Downing Street, Cambridge CB2 3ER, UK.

E-mail address: ELFL2@cam.ac.uk (E. Lightfoot).
} 
exploitation of bread wheat, being widespread, but differences are also seen in cropping strategies relating to the variability and seasonality of water availability (e.g. Petrie et al., 2017; Petrie and Bates, 2017; Vishnu-Mittre and Sacithri, 1982; Weber, 1999; Weber et al., 2010). There have been a number of important studies of animal exploitation at Indus sites (e.g. Joglekar et al., 2013; Meadow, 1996; Meadow and Patel, 2003; Sharada, 2018; Thomas, 2002), but there remains much to learn about Indus animal management strategies and whether or not these varied across the Indus Civilisation. Thus far, the use of stable isotope analysis has been limited (e.g. Chakraborty et al., 2018; Chase et al., 2014; Chase et al., 2020). Consideration of not only which animals were present but also how they were used and fed are essential for understanding the social processes related to animal management, and for considering the adaptation and sustainability of Indus pastoral agriculture and its resilience to climate change, particularly in relation to the $4.2 \mathrm{ka}$ BP climate 'event' and the deurbanisation of the Indus Civilisation by c.1900 BCE.

This paper presents a large new carbon isotope dataset from animal teeth from ancient settlement sites in northwest India. We infer the diets of cattle, water buffalo, sheep, goat, pig and various wild animals and consider the implication that these data have for human daily lives and social organisation. Samples from a range of settlement sizes are considered, allowing us to document the variety in animal management strategies within northwest India as compared to published data from contemporary sites in Gujarat (Chakraborty et al., 2018; Chase et al., 2014; Chase et al., 2020), which lies to the south. These two regions are important as they represent the two areas that lie at the easternmost edge of the distribution of Indus Civilisation settlements (Fig. 1a). By taking a diachronic perspective, we also consider how animal management strategies may have varied through time, and what this tells us about the sustainability and resilience of Indus animal management practices. The paper poses three specific questions. Do we observe the same isotopic patterning in all species? Do domesticated animals show the same isotopic patterning as wild animals? Do we see a change over time, space and site size?

\section{Background}

\subsection{The Indus Civilisation}

The Indus Civilisation stretched over the Indus River basin and its surrounding areas, spanning an extensive area of northwest India and Pakistan. It is characterised as having a phase of urbanism, but as there are only four or five known cities compared to thousands of smaller settlements (Fig. 1a), and it is likely that most people did not live in cities (Fairservis, 1961; Parikh and Petrie, 2019; Sinopoli, 2015). Pastoralism was an important component of urban and rural subsistence, and although pastoralism may have been attached to sedentary communities, it is possible that there were mobile pastoral communities coexisting with sedentary populations within the Indus zone (e.g. Guha, 1994), indeed pastoral communities existed in surrounding areas in the Mediaeval period (Varma, 1991). Direct evidence for mobile populations in the form of campsites is limited to Gujarat and Cholistan (e.g. Mughal, 1997; Rissman and Chitalwala, 1990). However, such sites are generally ephemeral, and evidence potentially will not have survived, particularly given the complicated alluvial sediment profiles associated with the Indus River basin and the extensive agriculture over parts of the region today.

There are a number of different chronological schemes for dividing up the periods of the Indus Civilisation, but most dating systems implicitly or explicitly divide the broad span into 'pre-urban', 'urban' and 'post-urban' phases (Possehl, 1977). These phases are alternatively referred to as 'Early Harappan' (3200-2600 BCE), 'Mature Harappan' (2600-1900 BCE, also known as the 'Harappa phase'; Kenoyer, 1998) and 'Late Harappan' (1900-1600 BCE; e.g. Mughal, 1970; Possehl, 2002; Wright, 2010). At Harappa, the urban phase is divided into three sub-phases, Harappa 3a (2600-2450 BCE), 3b (2450-2200 BCE), and 3c (2200-1900 BCE) (Kenoyer, 1991, 2008). However, the leitfossils that differentiate these phases are not always attested in regional assemblages, and cross-correlations are only possible with the assistance of radiocarbon dates. Here, we separate our samples from the Mature Harappan (MHar) period into three phases, MHar i (2600-2450 BCE), MHar ii (2450-2200 BCE) and MHar iii (2200-1900 BCE), which correspond chronologically to Harappa $3 \mathrm{a}, 3 \mathrm{~b}$ and $3 \mathrm{c}$. We adopt this approach to maintain coherence with the Harappa chronology, but also to emphasise that these sites present a regionally distinct manifestation of Indus material culture.

Today, the Indus River basin is environmentally diverse, incorporating areas of arid hot desert, arid hot steppe, and warm and temperate areas with dry winters and hot summers (Wright, 2010; Petrie, 2013, 2017; Petrie et al., 2017). Different areas receive water in the form of summer and/or winter rainfall, snowmelt from the Himalayas, and surface and river runoff from these features (Petrie et al., 2017). Palaeoclimatic proxy records are not evenly distributed across the region, but they do suggest complex patterns of variation in rainfall intensity across the Holocene, with higher levels of rainfall in the early Holocene, progressive aridification in the mid Holocene, some evidence for increasing precipitation c.4.5 ka BP, and then evidence of weakening winter and summer rainfall from c.4.3-4.2kya BP (Dixit et al., 2014, 2018; Giesche et al., 2019; see Dixit and Tandon, 2016; Misra et al., 2019). Geographically, the Indus River basin and its surrounding areas include alluvial plain, piedmonts, mountains, desert and coastal areas, and Indus settlements are found in each of these contexts.

This variation in water supply and geography would have (and continues to) produced a range of distinct ecological niches that influenced Indus agricultural strategies. Indus Civilisation populations cultivated a range of winter (rabi) crops including wheat and barley, and summer (kharif) crops including native millets, rice and tropical pulses (Petrie and Bates, 2017; Weber, 1999, 2003; Wright, 2010). Variation in past cropping strategies is seen between the different regions, resulting from the differences in ecological setting and water availability. It has been suggested by several scholars (Petrie and Bates, 2017; Weber, 1999; Weber et al., 2010) that winter crops predominate in Sindh and Baluchistan (e.g. Tengberg, 1999) while summer crops predominate in Gujarat, which does not benefit from winter rainfall (e.g. Reddy, 2003; Weber, 1991, 1999). In Pakistani Punjab, both winter and summer crops are found though winter crops predominate (e.g. Weber, 1999), whereas in Haryana and Punjab in northwest India, a diverse mix of winter and summer crops is attested (e.g. Bates, 2016; Petrie et al., 2016; Petrie and Bates, 2017; Üstünkaya et al., 2020). Nevertheless, there are some sites that seem to challenge this pattern, for example Kanmer in Gujarat where barley is attested in the Early and Mature Harappan (Pokharia et al., 2011) and Sohr Damb in Baluchistan where a diverse range of crops are found, including summer crops (Beneke and Neef, 2005). Significantly, some aspects of Indus cuisine appear to have been widespread in spite of ecological variability; bread wheat, for example, was used throughout the Indus zone even in areas not well suited to growing winter crops (Madella, 2014).

\subsection{Indus Zooarchaeology}

Broad surveys of the use of animals at Indus Civilisation settlements have suggested a degree of uniformity and/or homogeneity in terms of the species found (Joglekar et al., 2013; Meadow, 1996; Meadow and Patel, 2003; Miller, 2004). Regardless of site size, Indus zooarchaeological assemblages are characterised by a high proportion of cattle and/or water buffalo remains, with a smaller proportion of sheep/goat, along with a small representation of pig, wild terrestrial animals and aquatic resources (e.g. Joglekar et al., 2013; Meadow and Patel, 2003; Miller, 2004). The broad similarities do, however, mask multiple layers of variation in patterns of animal exploitation within and between Indus settlements. 


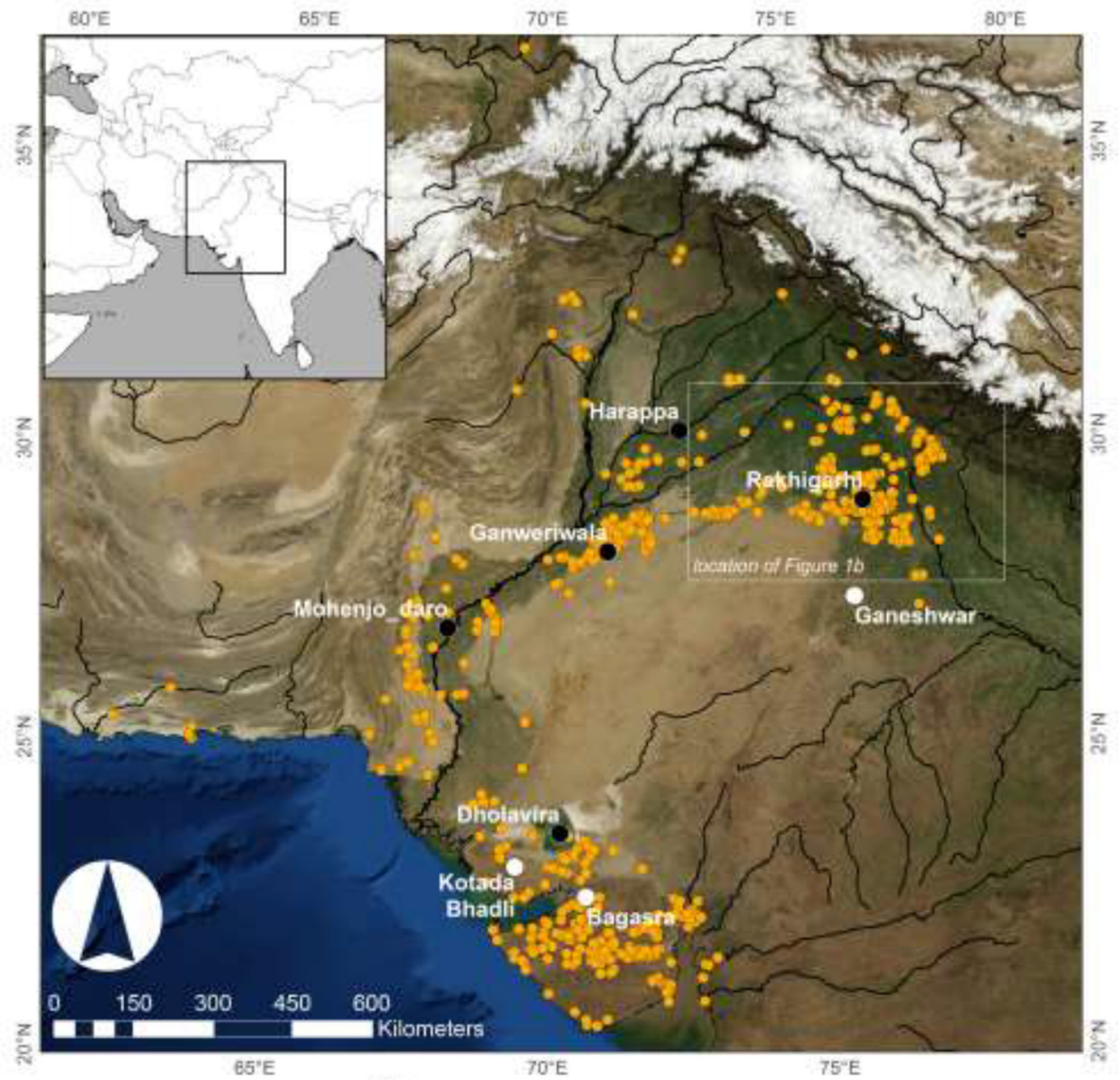

$75^{\circ} \mathrm{E}$

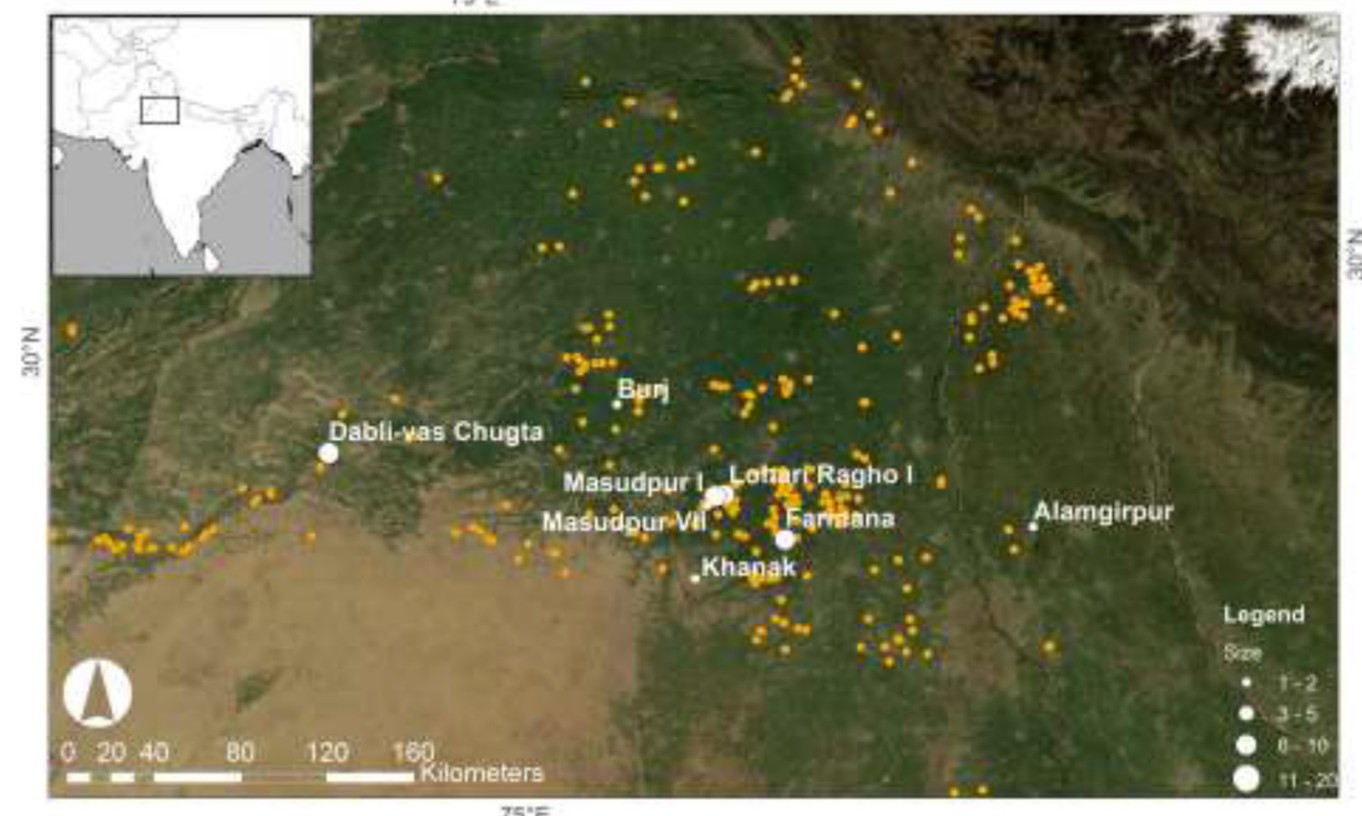

Fig. 1. Maps of sites mentioned in the text: a) Map of the Indus Civilization with known sites shown by orange circles, city sites by black circles and sites with animal carbon isotope data by white circles; b) Map of the studied region, with white circles indicating the sites in Haryana analysed as part of this study, where the size of the circle relates to the site size in hectares (see legend). 
Cattle and buffalo are the most abundant faunal species identified in Indus contexts, with their bones often comprising over $50 \%$ of the total sample (Joglekar et al., 2013; Miller, 2004; Thomas, 2002). Distinguishing between cattle and water buffalo remains is difficult, but studies indicate that cattle tend to outnumber buffalo (e.g. Harappa, Punjab: Miller, 2004; Dholavira, Gujarat: Patel, 2015), although the precise importance of cattle and water buffalo bones can vary between even relatively closely located settlements (e.g. Shikarpur and Bagasra, Gujarat: Chase, 2010, 2014). Cattle and water buffalo have markedly different water requirements, and it might be expected that proportions of water buffalo will have been exploited in areas with better water availability, though water buffalo have been attested in arid areas, such as at Dabli-vas Chugta in northern Rajasthan (Joglekar pers. comm.). Kill-off patterns tend to suggest that both species were kept primarily for their secondary products (Chase, 2010, 2014; Miller, 2004; Patel, 2015), although at Balakot, the kill-off pattern indicates that meat production was important (Meadow, 1979).

Sheep and goat bones typically make up c. $10 \%$ of the animal remains at Indus settlements (Thomas, 2002), but their widespread presence indicates that they were a fundamental part of the economic system. Studies suggest that the proportion of sheep and goat varied, likely related to the environmental conditions at the site mediated by their cultural importance (Meadow, 1991; Miller, 2004; Patel, 1997). Kill-off patterns indicate some differences in the primary aim of sheep and goat pastoralism between sites, with the animals kept primarily for meat at the small coastal settlements at Shikarpur and Bagasra (Chase, 2010, 2014), while secondary products seem to have been more important at Dholavira, Harappa and Nausharo (Meadow, 1991; Patel, 2015), which are situated in island, alluvial plain and piedmont contexts respectively.

Pigs are often found in Indus settlements, but they typically represent only $2-3 \%$ of the zooarchaeological assemblage (Joglekar et al., 2013; Thomas, 2002). The domestic status of these animals remains unclear (Chase, 2014), but it is possible that both wild and domestic pig were exploited (Deshpande-Mukherjee et al., 2007; Joglekar et al., 2016).

Variation in animal resource use can be seen within several settlements, for example, differences can be seen in species and element representation, as well as cutmark abundance between intra- and extramural assemblages at Shikarpur and Bagasra (Chase, 2010, 2012, 2014). There are also hints at developments in the animal economy through time, with changes in cattle slaughter ages suggesting an increase in the importance of secondary products at Balakot and Harappa, and potentially at the regional or civilisation level (Meadow, 1979; Miller, 2004). It is likely that this intensification of pastoral production, whether local or regional, was linked to the increased subsistence needs of an increasing urban population (Miller, 2004).

\subsection{Carbon isotope analysis as an indicator of diet}

Carbon isotope analysis of tooth enamel allows for an assessment of diet during the time of tooth formation. Here, carbon isotopes are used to distinguish between animal consumption patterns of two different types of plants, $\mathrm{C}_{3}$ and $\mathrm{C}_{4}$, which use different photosynthetic pathways (Vogel and Van der Merwe, 1977). Most plants use the $C_{3}$ photosynthetic pathway, including economically important plants such as wheat, barley and rice. Those species which follow the $\mathrm{C}_{4}$ pathway are mainly clustered within a restricted number of families largely comprising herbaceous genera, including the Graminae (grasses). Browsable leafy perennials are uncommon in those families, and are typically $\mathrm{C}_{3}$. Both natural grasslands and crop stands may in certain cases be dominated by $\mathrm{C} 4$ plants; $\mathrm{C} 4$ grasses may be abundant in tropical, arid and coastal ecosystems, while C4 crops include, maize, the millets, sorghum and sugar cane (Ehleringer and Monson, 1993). A literature review of plants in Haryana suggests that a small but notable proportion of edible plants in the region are $\mathrm{C}_{4}$ (today, a very rough estimate of
$13 \%$ of species edible to humans and/or animals use the $\mathrm{C}_{4}$ pathway, although note that this is by species not by biomass: Lightfoot et al., 2018). Free-roaming animals in arid environments globally have been observed to consume diets based on both $\mathrm{C}_{3}$ and $\mathrm{C}_{4}$ plants, with proportions varying throughout the year (Balasse et al., 2002; Cadwallader et al., 2012; Feranec et al., 2009; Makarewicz and Pederzani, 2017).

The carbon isotope values in plants are incorporated into tooth enamel at the time of tooth formation and not subsequently altered (Balasse, 2002). While enamel formation is complex, in hypsodont teeth (found in caprines and bovids, but not pigs and humans) enamel forms in such a way that a chronological sequence is represented down the length of the crown (Balasse, 2002, 2003). The period represented by a tooth varies depending upon the tooth analysed and the species in question; cattle and caprine M2s and M3s represent approximately the second and third year of life, respectively (Brown et al., 1960; Weinreb and Sharav, 1964). In animals eating a pure $C_{3}$ diet, variation in sequential enamel carbon isotope values can often be seen throughout the year due to seasonal variation in plant isotope values (Balasse, 2002, 2003; Heaton, 1999; O'Leary, 1988). In the mixed $\mathrm{C}_{3}-\mathrm{C}_{4}$ context of northwest India, however, we predict that any variations based on seasonal changes in plant isotope values will be swamped by variations in the proportion of $\mathrm{C}_{3}$ and $\mathrm{C}_{4}$ plants in the diet as this has the potential to induce much larger amounts of isotopic variation (Balasse, 2003; Chakraborty et al., 2018; Chase et al., 2014; Chase et al., 2020).

\section{Materials and methods}

Samples were selected from seven small settlement sites excavated by the Land, Water and Settlement and TwoRains projects (Petrie et al., 2017, 2019, 2020), and from a nearby settlement of Farmana, excavated by the Deccan College-RIHN Indus Project (Shinde et al., 2011). The Indus Civilisation phases of occupation at these sites provide the majority of our samples, though some individuals were sampled from later Painted Grey Ware and Early Historic period deposits for comparison. The sites range in size from 1 to $18 \mathrm{ha}$, and are situated in areas where modern rainfall amounts vary from 330 to $790 \mathrm{~mm} / \mathrm{annum}$. In addition, a small number of samples were taken from Ganeshwar, which is a Ganeshwar-Jodhpura Cultural Complex site located in Rajasthan that is broadly contemporary with the Early and Mature Harappan phases in Haryana (Singh et al., 2019; also Rizvi, 2007, 2013). The analysed sites are described in Appendix 1, summarised in Table 1 and shown in Fig. 1. Today, the sites are situated in semi-arid environments that have been completely transformed through modern farming. As best as we can currently ascertain, during the Indus period the sites would have been situated in relatively open grassland with various arid and riparian taxa (Üstünkaya et al., 2020).

At many of these sites, the availability of suitable faunal material has been severely limited by the preservation conditions. The teeth sampled were therefore often not the optimum samples for this type of analysis, but second and third molars were prioritised where possible. Domesticated animal teeth were collected from all sites, with wild animal teeth sampled wherever suitable teeth where available. In the case of hypsodont teeth (i.e. sheep, goat, cow and water buffalo, plus most of the wild species sampled here), sequential samples were taken where preservation permitted, with bulk enamel samples taken for the remaining teeth. Enamel powder samples were taken using a hand-held drill with a diamond drill bit attachment. For sequential samples, enamel subsamples were taken at perpendicular increments along a single cusp of the tooth, while bulk samples were taken along the length of the surviving crown. The pre-treatment method was based on that described in Balasse et al. (2002). $0.1 \mathrm{ml}$ of $2-3 \%$ aqueous sodium hypochlorite was added per mg of sample. The samples were then left for $24 \mathrm{~h}$ at $4{ }^{\circ} \mathrm{C}$ before being rinsed five times with distilled water to remove the sodium hypochlorite. After this $0.1 \mathrm{mg}$ of acetic acid was added per mg of sample. The samples were then left for $4 \mathrm{~h}$ at room temperature, before the acetic acid was removed and the samples were 
Table 1

Information about sites and samples studied for this work.

\begin{tabular}{|c|c|c|c|c|c|c|c|c|}
\hline Site name & Site code & Lat & Long & Phasing of samples & $\begin{array}{l}\text { Size of site } \\
\text { (ha) }\end{array}$ & $\begin{array}{l}\text { Modern rainfall } \\
(\mathrm{mm} / \mathrm{yr})\end{array}$ & $\begin{array}{l}\text { Koppen-Geigger climate } \\
\text { classification }\end{array}$ & Number of samples \\
\hline Alamgirpur & ALM & 29.00 & 77.37 & $\begin{array}{l}\text { MHar iii, PGW, Mediaeval/PGW, } \\
\text { Early Historic }\end{array}$ & 1 & 790 & Cwa: humid subtropical climate & 21 individuals \\
\hline Burj & BRJ & 29.66 & 75.64 & MHar i, PGW, Early Historic & 1 & 450 & BSh: semi-arid climate & 7 individuals \\
\hline Dabli-vas-Chugta & DVC & 29.53 & 74.17 & Mhar i, Mhar ii, Early Historic & 6 & 330 & BWh: desert climate & 13 individuals \\
\hline Farmana & FRM & 29.04 & 76.31 & MHar ii & 18 & 510 & BSh: semi-arid climate & 16 individuals \\
\hline Ganeshwar & GWR & 27.67 & 75.82 & GWR-JOD & 3 & 470 & BSh: semi-arid climate & 5 individuals \\
\hline Khanak & KNK & 28.91 & 75.87 & EHar & 1 & 440 & BSh: semi-arid climate & 4 individuals \\
\hline Lohari Ragho & LHR & 29.25 & 76.03 & MHar ii & 9 & 510 & BSh: semi-arid climate & 11 individuals \\
\hline Masudpur I & MSDI & 29.24 & 75.97 & MHar ii, MHar iii & 6 & 440 & BSh: semi-arid climate & 23 individuals \\
\hline Masudpur VII & MSDVII & 29.21 & 75.95 & MHar iii, ELHar & 1 & 440 & BSh: semi-arid climate & 14 individuals \\
\hline
\end{tabular}

Rainfall data from the NASA Langley Research Center [LaRC] POWER Project funded through the NASA Earth Science/Applied Science Program.

rinsed. Samples were then frozen and freeze-dried to remove any remaining liquid.

The samples were then transferred to a vial with a screw cap holding a septa and PCTFE washer to make a vacuum seal, and reacted with $100 \%$ orthophosphoric acid at $90{ }^{\circ} \mathrm{C}$ using a Micromass Multicarb Sample Preparation System. The carbon dioxide produced was dried and transferred cryogenically into a VG SIRA mass spectrometer for isotopic analysis. Carbon isotopic ratios are expressed as $\delta$ values on the international VPDB scale calibrated using the NBS19 standard (Coplen 1995; Craig 1957). Each run of samples was accompanied by 10 reference carbonates (Carrara Z) and 2 control samples (Fletton Clay). Carrara $\mathrm{Z}$ has been calibrated to VPDB using the international standard NBS19, and the precision is better than $\pm 0.08 \%$.

Statistical analyses were performed using Rstudio version 1.0.143 ( $\mathrm{R}$ Core Team, 2017). The code is available in Appendix 2, and the data file in Appendix 3. Samples were tested for normality using histograms and Shapiro-Wilks tests and for equality of variance using Levene's tests. Kolmogorov Smirnov Z tests were used for non-parametric data. Graphs were plotted using ggplot2 (Wickham, 2016).

\section{Results}

\subsection{Comparisons across all individuals}

We compared the data across all individuals. Where the enamel sample was taken as a bulk sample, we have used the single measured value. Where the enamel was sampled sequentially from one tooth, we have used the median value. Where two teeth were analysed sequentially from one individual, we used the median value of both teeth combined.

Bovids had higher carbon isotopic values than ovicaprids (cow and water buffalo versus sheep and goat: two-sampled Kolmogorov-Smirnov $\mathrm{Z}$ test, $\mathrm{D}=0.89899, p<.001$, Mature Harappan period only), and the few pigs and boar had values towards the bottom of the isotopic range for all domestic animals (Fig. 2, Table 2). Although sample size is limited we note that sheep and goat have similar carbon isotope ratios despite sheep being primarily grazers and goats primarily browsers. The wild animals (all of which are ruminant) show a wide range of $\delta^{13} \mathrm{C}$ values. There is no apparent correlation between whether a species is classified as a browser or a grazer and its carbon isotope ratio. For example, blackbuck is classified as a grazer and yet has both low and high measured $\delta^{13} \mathrm{C}$ values, while some four-horned antelope samples have very high carbon isotope ratios despite being classified as a browser.

\subsection{Intra-individual variation}

The $\delta^{13} \mathrm{C}$ results of the sequential samples are summarised by tooth in Table 3 and listed in full in Appendix 4. Collectively, the wild animals show an extremely wide range of values, spanning from -8.6 to 4.3\%o ( $\mathrm{n}=15$ teeth, $\mathrm{n}=80$ sub-samples, excluding Sus scrofa) (Fig. 3). The range found in individual teeth is generally large (ten have ranges over 1\%o) although there are some notable exceptions, such as KNK01 (Axis axis, 9 samples, range $=1.0 \%$ ). Within the wild animal species sampled, different individuals follow different browsing and grazing patterns over time, as visible in the varied intra-individual ranges observed, notably for blackbuck (Antilope cervicapra) and four-horned antelope (Tetracerus quadricornus).

In the domestic species, the cattle and water buffalo results show similar patterns to each other over time and site (Figs. 4 and 5 by time, Fig. 6 by site), with each individual showing little isotopic change along the length of the tooth - the mean range for both cattle ( $n=56$ teeth, $\mathrm{n}=509$ subsamples) and water buffalo ( $\mathrm{n}=11$ teeth, $\mathrm{n}=83$ subsamples) is $1.1 \%$. The sheep and goat show a different pattern to the bovids, although the sample size is considerably smaller ( $\mathrm{n}=15$ teeth, $\mathrm{n}=95$ subsamples). In the urban phase (Mature Harappan), the sheep and goat show higher variation within a tooth than the cattle and water buffalo, tested using both the intra-individual range and also the variance across those ranges (mean intra-individual range in ovicaprids $=3.8 \%, \mathrm{n}=11$, mean intra-individual range in bovids $=1.1 \%$, $\mathrm{n}=43$, two-sampled Kolmogorov-Smirnov $\mathrm{Z}$ test, $\mathrm{D}=0.77167$, $\mathrm{p}<$.001; Levene's test on variation of intra-individual ranges, $\mathrm{df}=1$, $52, \mathrm{~F}=27.262, \mathrm{p}<.001$ ), although we note that the sample sizes are unequal. For samples that post-date the urban phase, the isotopic patterning varies. The single Late Harappan goat shows high isotopic variation (MSD_191, mean $=-1.3 \%$, range $=4.7 \%$ ). The three postIndus sheep and goat samples show less intra-individual variation and have higher $\delta^{13} \mathrm{C}$ values than the earlier dated sheep and goat teeth (Fig. 4).

The cattle and water buffalo teeth from Ganeshwar, which is a contemporary but non-Indus site, also follow the pattern seen for these species at the other sites, having relatively high $\delta^{13} \mathrm{C}$ values with little isotopic variation within each tooth (minimum $\delta^{13} \mathrm{C}$ value $=-1.5 \%$, maximum range $=1.6 \%, \mathrm{n}=4$ teeth).

There are some exceptions to the patterns of consistent and high bovid $\delta^{13} \mathrm{C}$ and variable ovcaprid $\delta^{13} \mathrm{C}$ over time. For instance, a few cattle and water buffalo have lower values than others (e.g. during MHar ii and MHar iii from both Masudpur I and Alamgirpur: Figs. 5 and 6), but even these samples have generally high $\delta^{13} \mathrm{C}$ values and relatively low ranges of values within each tooth. There are also some sheep and goat with isotope values more akin to the cattle, most notably sample ALM_135, which is the only urban period ovicaprid sampled from Alamgirpur.

\section{Discussion}

\subsection{Animal management strategies across space and over time}

Using the expected offsets between isotopic values of diet and tooth enamel $(+14.6 \%$ for ruminants and $+13.3 \%$ for pigs $)$, our data 


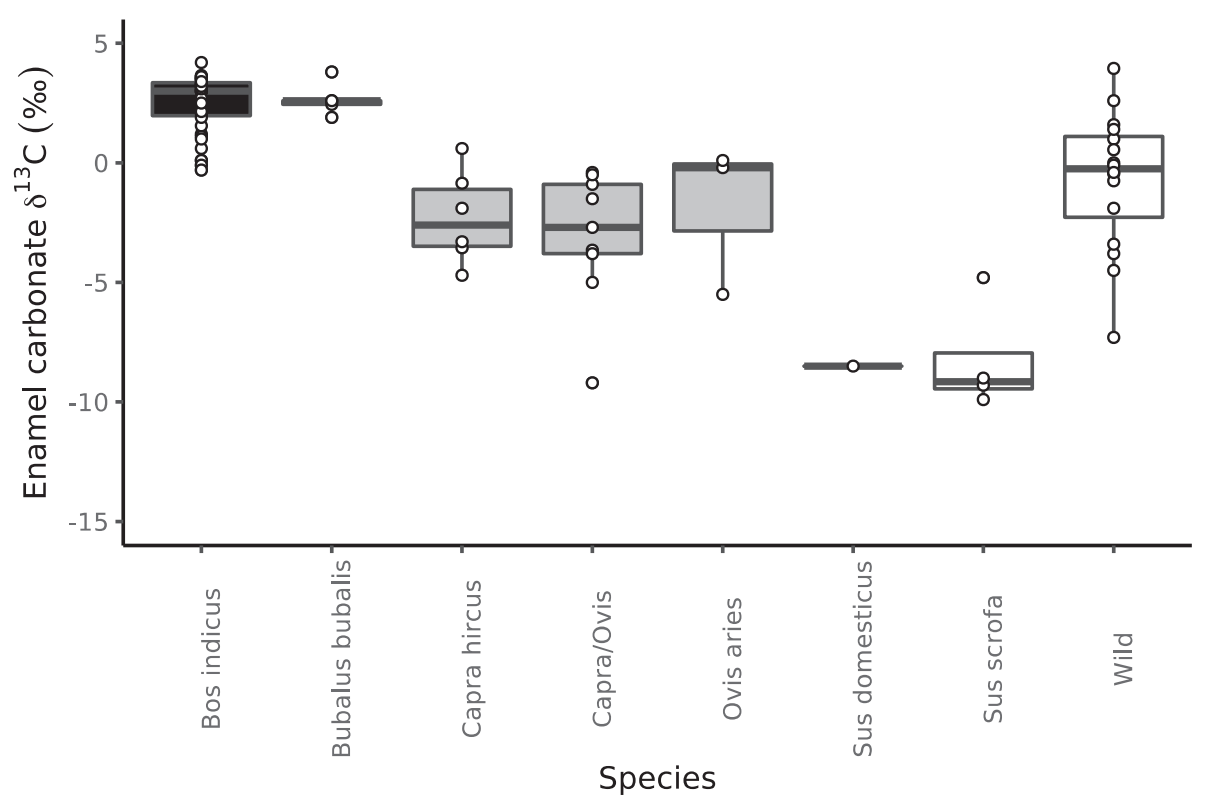

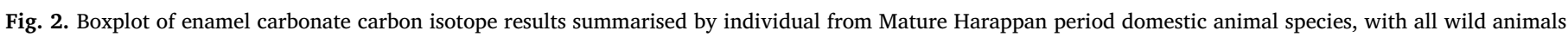
shown for comparison.

Table 2

Summary of tooth enamel carbon isotope data from the Mature Harappan period by species.

\begin{tabular}{|c|c|c|c|c|c|c|c|}
\hline \multirow[t]{2}{*}{ Species } & \multirow[t]{2}{*}{$\mathrm{n}$} & \multicolumn{6}{|c|}{$\delta^{13} \mathrm{C}(\% 0)$} \\
\hline & & Mean & $\begin{array}{l}\text { Standard } \\
\text { deviation }\end{array}$ & IQR & Minimum & Maximum & Range \\
\hline Bos indicus & 39 & 2.5 & 1.2 & 1.4 & -0.3 & 4.2 & 4.6 \\
\hline Bubalus bubalis & 5 & 2.7 & 0.7 & 0.2 & 1.9 & 3.8 & 1.9 \\
\hline Capra hircus & 6 & -2.3 & 2.0 & 2.4 & -4.7 & 0.6 & 5.3 \\
\hline Capra/Ovis & 9 & -3.1 & 2.8 & 2.9 & -9.2 & -0.4 & 8.7 \\
\hline Ovis aries & 3 & -1.9 & 3.2 & 2.8 & -5.5 & 0.1 & 5.6 \\
\hline Sus domesticus & 1 & -8.5 & NA & NA & NA & NA & NA \\
\hline Sus scrofa & 4 & -8.3 & 2.3 & 1.5 & -9.9 & -4.8 & 5.0 \\
\hline
\end{tabular}

indicate domestic and wild animal dietary intakes range from predominantly $\mathrm{C}_{3}$ to predominantly $\mathrm{C}_{4}$ (Passey et al., 2005). Some of the wild animals show marked seasonal variation in the relative proportions of $\mathrm{C}_{3}$ and $\mathrm{C}_{4}$ in their diets, while others vary little throughout the time represented by the samples. These data support the assertion that the landscape contained a mixture of $\mathrm{C}_{3}$ and $\mathrm{C}_{4}$ plants, and indicate that specialised consumption of $\mathrm{C}_{4}$ species was a plausible strategy for some but not all individuals. No individuals consumed a diet that was solely or largely reliant upon $\mathrm{C}_{3}$ plants. Notably, wild animal diets do not show a division between browsers and grazers with a wide range of values seen within both predominantly browsing species (i.e. Tetracerus quadricornus) and predominantly grazing species (i.e. Antilope cervicapra).

The carbon stable isotope results show that the cows and water buffalo consumed diets that were extremely high in $\mathrm{C}_{4}$ foodstuffs (dietary input of $-12.1 \%$ for Mature Harappan cattle, for example). These diets were consistent both through the time of tooth formation and across the chronological periods represented by the samples analysed here (i.e. Early Harappan through to Mediaeval). The diets were also consistent across the environmental zones and the different sizes of settlements represented by these samples. The tooth enamel of three cattle and one water buffalo from Ganeshwar, which is not an Indus Civilisation site, also show this pattern, as do cattle and water buffalo analysed from Bagasra, Shikarpur and Jaidak in Gujarat (Chase et al., 2014; Chase et al., 2020). The published data from the contemporary
Sorath culture site Kotada Bhadli, Gujarat have slightly lower, and possibly more varied, carbon isotope values, but are still indicative of a diet that was largely reliant upon $\mathrm{C}_{4}$ plants year-round (Chakraborty et al., 2018). The consistency and dominance of $\mathrm{C}_{4}$ plants in cattle and water buffalo diets, combined with the expectation that the landscape contained a mixture of $\mathrm{C}_{3}$ and $\mathrm{C}_{4}$ species (Shoko et al., 2016; Lightfoot et al., 2018) and the range of diets apparent in the wild animal dataset regardless of whether the species are browsers or grazers, suggests that the diets of cattle and water buffalo were constrained and controlled by humans throughout the year. If these animals ate freely one would expect to see more variation in the cow and water buffalo diets. Human control of these animal diets could include giving the cows and water buffalo access to millet fields after harvest, as well as more direct foddering of wild and/or domesticated $\mathrm{C}_{4}$ plant species to these animals.

During the Indus urban period (i.e. Mature Harappan), the sheep and goats show a range of carbon isotope values within a tooth indicating a more varied diet (in terms of the ratio of $\mathrm{C}_{3}$ to $\mathrm{C}_{4}$ plants) throughout the time of tooth formation. The sample size is much more limited than for cattle and water buffalo, due to the lower numbers of sheep and goat found on Indus sites, combined with the poorer preservation of sheep and goat teeth compared to larger cow and water buffalo teeth. Nevertheless, there does not seem to be a difference in diet between sheep and goats based on their preference for browse or graze. Furthermore, the dietary pattern for sheep and goat seems to be consistent across the Indus sites analysed here, and is similar to the pattern found at Bagasra, Shikarpur, Jaidak and Kotada Bhadli, although at this latter site there is one sheep with carbon isotope values indicative of $\mathrm{a} \mathrm{C}_{4}$ dominated diet (Chakraborty et al., 2018; Chase et al., 2014; Chase et al., 2020). The single Late Harappan individual also seems to follow this pattern, as do the Late Harappan individuals from Jaidak. The data suggest that the sheep and goat generally consumed a seasonally varied diet, which at times was dominated by $\mathrm{C}_{4}$ plants and at other times contained a high proportion of $\mathrm{C}_{3}$ plants. The lack of dietary consistency both within and between individuals suggest that humans exerted far less control over the diets of sheep and goat than over cow and water buffalo, although direct foddering of sheep and goat using $\mathrm{C}_{3}$ and/or $\mathrm{C}_{4}$ plants at various times of the year remains possible. This similarity in diet between sheep and goat is somewhat surprising given their well-known preferences for graze and browse, 
Table 3

Enamel carbonate carbon isotope data from bulk and sequential intra-tooth samples summarised by individual.

\begin{tabular}{|c|c|c|c|c|c|c|c|c|c|c|}
\hline \multirow[t]{2}{*}{ Specimen } & \multirow[t]{2}{*}{ Tooth } & \multirow[t]{2}{*}{ Species } & \multirow[t]{2}{*}{ Site } & \multirow[t]{2}{*}{ Period } & \multirow[t]{2}{*}{$\mathrm{n}$} & \multicolumn{5}{|l|}{$\delta^{13} \mathrm{C}(\%)$} \\
\hline & & & & & & Minimum & Maximum & Mean & Median & Range \\
\hline ALM_031 & M1/M2 & Sus scrofa & ALM & MHar & 1 & -9.3 & -9.3 & -9.3 & -9.3 & 0.0 \\
\hline ALM_033 & M2 & Bos indicus & ALM & MHar & 6 & 1.9 & 2.9 & 2.2 & 2.1 & 1.0 \\
\hline ALM_034 & M2 & Bos indicus & ALM & MHar & 5 & -0.6 & 2.6 & 1.1 & 1.2 & 3.2 \\
\hline ALM_035 & M2 & Boselaphus tragocamelus & ALM & MHar & 5 & 0.6 & 2.9 & 1.7 & 1.6 & 2.3 \\
\hline ALM_036 & M3 & Bos indicus & ALM & MHar & 8 & 2.8 & 3.8 & 3.4 & 3.5 & 1.0 \\
\hline ALM_088 & $\mathrm{m} 3$ & Antilope cervicapra & ALM & MHar & 2 & -2.6 & 1.7 & -0.5 & -0.5 & 4.3 \\
\hline ALM_102 & M1 & Sus domesticus & ALM & PGW & 1 & -11.9 & -11.9 & -11.9 & -11.9 & 0.0 \\
\hline ALM_114 & M1 & Sus domesticus & ALM & PGW & 1 & -11.6 & -11.6 & -11.6 & -11.6 & 0.0 \\
\hline ALM_126 & M2 & Sus scrofa & ALM & MHar & 1 & -9.9 & -9.9 & -9.9 & -9.9 & 0.0 \\
\hline ALM_128 & M3 & Bos gaurus & ALM & MHar & 5 & -1.4 & 1.3 & -0.1 & 0.0 & 2.7 \\
\hline ALM_135 & $\mathrm{m} 3$ & Ovis aries & ALM & MHar & 7 & -2.1 & 1.2 & -0.5 & -0.2 & 3.3 \\
\hline ALM_152 & M2 & Bos indicus & ALM & MHar & 10 & 0.7 & 2.3 & 1.5 & 1.6 & 1.6 \\
\hline ALM_153 & M3 & Bos indicus & ALM & MHar & 9 & -0.6 & 1.5 & 0.2 & 0.1 & 2.1 \\
\hline ALM_183 & M3 & Bos indicus & ALM & PGW & 8 & 3.6 & 4.2 & 3.8 & 3.8 & 0.6 \\
\hline ALM_196 & M2 & Tetracerus quadricornus & ALM & PGW & 7 & 0.1 & 4.1 & 1.6 & 1.0 & 4.0 \\
\hline ALM_200 & M1/M2 & Capra hircus & ALM & Medieval/PGW & 1 & -1.8 & -1.8 & -1.8 & -1.8 & 0.0 \\
\hline ALM_230 & M1/M2 & Capra/Ovis & ALM & Early Historic & 10 & -0.4 & 1.0 & 0.3 & 0.3 & 1.4 \\
\hline ALM_232 & M1 & Capra hircus & ALM & Early Historic & 5 & 0.4 & 1.3 & 0.8 & 0.7 & 0.9 \\
\hline ALM_259 & $\mathrm{m} 3$ & Antilope cervicapra & ALM & PGW & 6 & -1.0 & 1.8 & 0.6 & 0.6 & 2.8 \\
\hline ALM_NN011 & M3 & Bos indicus & ALM & PGW & 7 & 2.9 & 3.8 & 3.5 & 3.5 & 0.9 \\
\hline ALMNNN_013 & M1/M2 & Capra/Ovis & ALM & PGW & 8 & 0.5 & 2.6 & 1.7 & 1.9 & 2.1 \\
\hline BRJ_636 & $\mathrm{m} 2$ & Tetracerus quadricornus & BRJ & PGW & 3 & 2.3 & 3.0 & 2.6 & 2.6 & 0.7 \\
\hline BRJ_648 & $\mathrm{m} 2$ & Tetracerus quadricornus & BRJ & PGW & 3 & -4.6 & -4.1 & -4.4 & -4.5 & 0.5 \\
\hline BRJ_652 & M1/M2 & Bos indicus & BRJ & PGW & 1 & 2.7 & 2.7 & 2.7 & 2.7 & 0.0 \\
\hline BRJ_655 & M3 & Bos indicus & BRJ & PGW & 9 & 2.8 & 3.6 & 3.2 & 3.1 & 0.8 \\
\hline BRJ_686 & $\mathrm{m} 3$ & Bos indicus & BRJ & MHar & 10 & 2.9 & 3.6 & 3.3 & 3.3 & 0.7 \\
\hline BRJ_808 & M3 & Bos indicus & BRJ & Early Historic & 11 & 2.7 & 3.8 & 3.1 & 3.1 & 1.1 \\
\hline BRJ_NN01 & M1/M2 & Bos indicus & BRJ & PGW & 1 & 1.5 & 1.5 & 1.5 & 1.5 & 0.0 \\
\hline DVC_018 & M3 & Capra hircus & DVC & MHar & 1 & -1.9 & -1.9 & -1.9 & -1.9 & 0.0 \\
\hline DVC_107 & $\mathrm{m} 3$ & Bos indicus & DVC & MHar & 9 & 2.5 & 3.4 & 3.1 & 3.3 & 0.9 \\
\hline DVC_130 & M1 & Capra/Ovis & DVC & MHar & 1 & -9.2 & -9.2 & -9.2 & -9.2 & 0.0 \\
\hline DVC__-222 & M3 & Capra hircus & DVC & MHar & 2 & -3.9 & -3.2 & -3.6 & -3.6 & 0.7 \\
\hline DVC_225 & M2 & Bos indicus & DVC & MHar & 5 & 3.0 & 4.0 & 3.5 & 3.5 & 1.0 \\
\hline DVC_279 & M3 & Bubalus bubalis & DVC & Early Historic & 9 & 3.2 & 3.7 & 3.6 & 3.6 & 0.5 \\
\hline DVC_502 & M2 & Bubalus bubalis & DVC & MHar & 5 & 1.3 & 3.2 & 2.3 & 2.6 & 1.9 \\
\hline DVC_509 & $\mathrm{m} 2$ & Bos indicus & DVC & MHar & 7 & 1.2 & 2.2 & 1.8 & 1.9 & 1.0 \\
\hline DVC_530 & DP4 & Antilope cervicapra & DVC & MHar & 1 & -7.3 & -7.3 & -7.3 & -7.3 & 0.0 \\
\hline DVC_554 & M2 & Sus scrofa & DVC & MHar & 1 & -9.0 & -9.0 & -9.0 & -9.0 & 0.0 \\
\hline DVC_558 & M2 & Capra hircus & DVC & MHar & 2 & -0.9 & -0.8 & -0.9 & -0.9 & 0.1 \\
\hline DVC_560 & M2 & Cervus unicolor & DVC & MHar & 6 & -1.8 & 1.9 & -0.4 & -0.8 & 3.7 \\
\hline DVC_561 & M1/M2 & Capra hircus & DVC & MHar & 4 & -6.1 & -2.4 & -3.8 & -3.3 & 3.7 \\
\hline FR_1704 & M3 & Bos indicus & FRM & MHar & 11 & 0.4 & 1.9 & 0.9 & 0.6 & 1.5 \\
\hline FR_1706 & M2 & Bos indicus & FRM & MHar & 11 & 2.0 & 3.7 & 3.0 & 3.0 & 1.7 \\
\hline FR_1709 & M3 & Bos indicus & FRM & MHar & 14 & 2.1 & 3.2 & 2.7 & 2.7 & 1.1 \\
\hline FR_1711 & M2 & Bos indicus & FRM & MHar & 5 & 2.3 & 2.7 & 2.5 & 2.6 & 0.4 \\
\hline FR_1711 & M3 & Bos indicus & FRM & MHar & 8 & 2.9 & 3.1 & 3.0 & 3.0 & 0.2 \\
\hline FR_1713 & M3 & Ovis aries & FRM & MHar & 12 & -9.5 & -3.2 & -6.1 & -5.5 & 6.3 \\
\hline FR_1716 & M1/M2 & Capra/Ovis & FRM & MHar & 3 & -3.2 & -0.7 & -1.6 & -0.9 & 2.5 \\
\hline FR_1717 & M1/M2 & Capra/Ovis & FRM & MHar & 9 & -7.3 & 0.2 & -4.0 & -5.0 & 7.5 \\
\hline FR_1718 & M3 & Bos indicus & FRM & MHar & 4 & 4.2 & 4.3 & 4.2 & 4.2 & 0.1 \\
\hline FR_1720 & M3 & Bos indicus & FRM & MHar & 15 & 2.5 & 3.4 & 3.0 & 3.0 & 0.9 \\
\hline FR_1721 & M3 & Bos indicus & FRM & MHar & 15 & 2.5 & 3.7 & 3.3 & 3.3 & 1.2 \\
\hline FR_1724 & M3 & Bos indicus & FRM & MHar & 13 & 3.2 & 3.8 & 3.5 & 3.6 & 0.6 \\
\hline FR_1728 & M1 & Capra/Ovis & FRM & MHar & 1 & -0.4 & -0.4 & -0.4 & -0.4 & 0.0 \\
\hline FR_1729 & M3 & Bos indicus & FRM & MHar & 17 & 2.7 & 3.4 & 3.0 & 3.0 & 0.7 \\
\hline FR_1730 & M3 & Bos indicus & FRM & MHar & 1 & -0.3 & -0.3 & -0.3 & -0.3 & 0.0 \\
\hline FR_1731 & M3 & Bos indicus & FRM & MHar & 21 & 2.7 & 3.6 & 3.1 & 3.1 & 0.9 \\
\hline FR_1732 & M3 & Antelope & FRM & MHar & 9 & 0.9 & 2.1 & 1.4 & 1.4 & 1.2 \\
\hline GWR032 & M2 & Bos indicus & GWR & GWR-JOD & 4 & -1.5 & -0.6 & -1.0 & -1.0 & 0.9 \\
\hline GWR252 & M2 & Bos indicus & GWR & GWR-JOD & 5 & 1.4 & 1.7 & 1.6 & 1.6 & 0.3 \\
\hline GWR548 & M2 & Bubalus bubalis & GWR & GWR-JOD & 5 & -1.0 & -0.3 & -0.6 & -0.6 & 0.7 \\
\hline GWR554 & M2 & Boselaphus tragocamelus & GWR & GWR-JOD & 5 & -1.6 & 0.2 & -0.5 & -0.1 & 1.8 \\
\hline GWR75 & M2 & Bos indicus & GWR & GWR-JOD & 6 & 0.3 & 1.9 & 0.9 & 0.8 & 1.6 \\
\hline KNK01 & max molar & Axis axis & KNK & EHar & 9 & -0.9 & 0.1 & -0.5 & -0.4 & 1.0 \\
\hline KNK02 & mandible & Bos indicus & KNK & EHar & 12 & 0.8 & 2.2 & 1.4 & 1.5 & 1.4 \\
\hline KNK03 & mandible & Bos indicus & KNK & EHar & 13 & 3.3 & 4.3 & 3.8 & 3.8 & 1.0 \\
\hline KNK04 & maxilla & Bos indicus & KNK & EHar & 9 & 2.9 & 4.2 & 3.5 & 3.4 & 1.3 \\
\hline LHR02 & LRM2 & Bos indicus & LHR & MHar & 6 & 2.1 & 2.8 & 2.6 & 2.7 & 0.7 \\
\hline LHR02 & LRM3 & Bos indicus & LHR & MHar & 10 & 1.7 & 3.2 & 2.3 & 2.3 & 1.5 \\
\hline LHR03 & LLM2 & Bos indicus & LHR & MHar & 15 & 2.2 & 2.9 & 2.5 & 2.4 & 0.7 \\
\hline LHR05 & LRM2 & Bos indicus & LHR & MHar & 13 & 3.0 & 3.7 & 3.4 & 3.5 & 0.7 \\
\hline LHR05 & LRM3 & Bos indicus & LHR & MHar & 13 & 3.4 & 4.2 & 3.9 & 3.9 & 0.8 \\
\hline
\end{tabular}


Table 3 (continued)

\begin{tabular}{|c|c|c|c|c|c|c|c|c|c|c|}
\hline \multirow[t]{2}{*}{ Specimen } & \multirow[t]{2}{*}{ Tooth } & \multirow[t]{2}{*}{ Species } & \multirow[t]{2}{*}{ Site } & \multirow[t]{2}{*}{ Period } & \multirow[t]{2}{*}{$\mathrm{n}$} & \multicolumn{5}{|l|}{$\delta^{13} \mathrm{C}(\% 0)$} \\
\hline & & & & & & Minimum & Maximum & Mean & Median & Range \\
\hline LHR07 & ULM3 & Bos indicus & LHR & MHar & 11 & 2.4 & 3.2 & 2.7 & 2.7 & 0.8 \\
\hline LHR08 & LLM2 & Bos indicus & LHR & MHar & 14 & 1.7 & 3.1 & 2.2 & 2.2 & 1.4 \\
\hline LHR09 & LLM3 & Bos indicus & LHR & MHar & 12 & 2.1 & 2.6 & 2.4 & 2.5 & 0.5 \\
\hline LHR11 & URM2 & Capra/Ovis & LHR & MHar & 1 & -3.8 & -3.8 & -3.8 & -3.8 & 0.0 \\
\hline LHR11 & URM3 & Capra/Ovis & LHR & MHar & 1 & -2.7 & -2.7 & -2.7 & -2.7 & 0.0 \\
\hline LHR12 & ULM2 & Bubalus bubalis & LHR & MHar & 5 & 1.0 & 2.1 & 1.6 & 1.6 & 1.1 \\
\hline LHR12 & ULM3 & Bubalus bubalis & LHR & MHar & 9 & 1.5 & 2.5 & 1.9 & 1.9 & 1.0 \\
\hline LHR13 & URM2 & Bos indicus & LHR & MHar & 13 & 3.0 & 3.5 & 3.3 & 3.3 & 0.5 \\
\hline LHR14 & LRM3 & Bos indicus & LHR & MHar & 13 & 2.8 & 3.7 & 3.2 & 3.1 & 0.9 \\
\hline LHR15 & LRM2 & Bubalus bubalis & LHR & MHar & 5 & 3.0 & 4.0 & 3.5 & 3.6 & 1.0 \\
\hline LHR15 & LRM3 & Bubalus bubalis & LHR & MHar & 9 & 1.9 & 2.9 & 2.3 & 2.2 & 1.0 \\
\hline MSD_01 & M3 & Capra/Ovis & MSDI & MHar & 1 & -0.5 & -0.5 & -0.5 & -0.5 & 0.0 \\
\hline MSD_02 & M3 & Capra/Ovis & MSDI & MHar & 12 & -6.9 & -0.4 & -3.3 & -3.7 & 6.5 \\
\hline MSD_023 & M2 & Ovis aries & MSDI & MHar & 2 & -1.5 & 1.7 & 0.1 & 0.1 & 3.2 \\
\hline MSD_025 & M1/M2 & Bos indicus & MSDI & MHar & 1 & 1.0 & 1.0 & 1.0 & 1.0 & 0.0 \\
\hline MSD_026 & $\mathrm{M} 1 / \mathrm{M} 2$ & Bos indicus & MSDI & MHar & 1 & 3.5 & 3.5 & 3.5 & 3.5 & 0.0 \\
\hline MSD_03 & M2 & Bos indicus & MSDI & MHar & 10 & -1.2 & 2.2 & 0.2 & 0.1 & 3.4 \\
\hline MSD_031 & M1 & Sus scrofa & MSDI & MHar & 1 & -4.8 & -4.8 & -4.8 & -4.8 & 0.0 \\
\hline MSD_04 & M2 & Bubalus bubalis & MSDI & MHar & 10 & 1.6 & 3.2 & 2.6 & 2.6 & 1.6 \\
\hline MSD_044 & $\mathrm{m} 3$ & Capra hircus & MSDI & MHar & 5 & -6.3 & -0.8 & -4.0 & -4.7 & 5.5 \\
\hline MSD_05 & M2 & Bos indicus & MSDI & MHar & 10 & -0.2 & 1.6 & 1.0 & 1.1 & 1.8 \\
\hline MSD_063 & M2 & Capra/Ovis & MSDI & MHar & 1 & -1.5 & -1.5 & -1.5 & -1.5 & 0.0 \\
\hline MSD_076 & $\mathrm{m} 3$ & Bubalus bubalis & MSDI & MHar & 3 & 3.7 & 4.0 & 3.8 & 3.8 & 0.3 \\
\hline MSD_077 & $\mathrm{m} 2$ & Boselaphus tragocamelus & MSDI & MHar & 4 & 3.3 & 4.3 & 3.9 & 4.0 & 1.0 \\
\hline MSD_089 & $\mathrm{M} 1 / \mathrm{M} 2$ & Bos indicus & MSDI & MHar & 1 & 3.5 & 3.5 & 3.5 & 3.5 & 0.0 \\
\hline MSD_092 & M2 & Bos indicus & MSDI & MHar & 6 & 2.4 & 3.9 & 3.2 & 3.2 & 1.5 \\
\hline MSD_101 & M2 & Antilope cervicapra & MSDI & MHar & 4 & -8.6 & -3.8 & -6.7 & -7.2 & 4.8 \\
\hline MSD_101 & M3 & Antilope cervicapra & MSDI & MHar & 5 & -4.6 & -1.5 & -2.8 & -3.0 & 3.1 \\
\hline MSD_125 & M1 & Sus domesticus & MSDI & MHar & 1 & -8.5 & -8.5 & -8.5 & -8.5 & 0.0 \\
\hline MSD_139 & M2 & Bos indicus & MSDI & MHar & 7 & 3.1 & 3.5 & 3.3 & 3.2 & 0.4 \\
\hline MSD_15 & M1 & Capra hircus & MSDVII & MHar & 9 & -0.9 & 1.7 & 0.4 & 0.6 & 2.6 \\
\hline MSD_155 & $\mathrm{M} 1 / \mathrm{M} 2$ & Bos indicus & MSDI & MHar & 1 & 3.6 & 3.6 & 3.6 & 3.6 & 0.0 \\
\hline MSD_156 & M2 & Bos indicus & MSDI & MHar & 1 & 3.4 & 3.4 & 3.4 & 3.4 & 0.0 \\
\hline MSD_175 & M2 & Bubalus bubalis & MSDVII & LHar & 12 & 1.2 & 3.3 & 2.6 & 2.8 & 2.1 \\
\hline MSD_176 & $\mathrm{M} 1 / \mathrm{M} 2$ & Antilope cervicapra & MSDVII & LHar & 1 & -3.4 & -3.4 & -3.4 & -3.4 & 0.0 \\
\hline MSD_177 & M2 & Bubalus bubalis & MSDVII & LHar & 11 & 3.5 & 4.4 & 3.9 & 3.7 & 0.9 \\
\hline MSD_191 & M2 & Capra hircus & MSDVII & LHar & 5 & -4.2 & 0.5 & -1.3 & -1.2 & 4.7 \\
\hline MSD_5115 & M2 & Bos indicus & MSDVII & LHar & 2 & 3.3 & 3.5 & 3.4 & 3.4 & 0.2 \\
\hline MSD_5115 & M3 & Bos indicus & MSDVII & LHar & 4 & 2.2 & 2.4 & 2.3 & 2.3 & 0.2 \\
\hline MSD_5117 & M3 & Bos indicus & MSDVII & LHar & 2 & 3.8 & 3.9 & 3.9 & 3.9 & 0.1 \\
\hline MSD_5118 & M3 & Bos indicus & MSDVII & LHar & 10 & 3.7 & 4.6 & 4.0 & 4.0 & 0.9 \\
\hline MSD_5121 & M2 & Bos indicus & MSDVII & LHar & 5 & 3.9 & 4.2 & 4.1 & 4.1 & 0.3 \\
\hline MSD_5125 & $\mathrm{m} 3$ & Bos indicus & MSDVII & LHar & 4 & -1.0 & 0.9 & 0.1 & 0.3 & 1.9 \\
\hline MSD_5126 & M3 & Bos indicus & MSDVII & LHar & 6 & 3.6 & 4.0 & 3.7 & 3.6 & 0.4 \\
\hline MSD_5145 & M3 & Sus scrofa & MSDVII & LHar & 1 & -5.7 & -5.7 & -5.7 & -5.7 & 0.0 \\
\hline MSD_5146a & $\mathrm{M} 1 / \mathrm{M} 2$ & Bos indicus & MSDVII & LHar & 3 & 1.0 & 3.1 & 1.9 & 1.5 & 2.1 \\
\hline MSD_5146b & M2 & Bos indicus & MSDVII & LHar & 9 & 0.7 & 4.1 & 2.4 & 2.4 & 3.4 \\
\hline MSD_5153 & M2 & Bos indicus & MSDVII & LHar & 5 & 3.2 & 3.6 & 3.4 & 3.5 & 0.4 \\
\hline MSD_NN010 & M3 & Bos indicus & MSDI & MHar & 11 & 3.0 & 4.0 & 3.6 & 3.6 & 1.0 \\
\hline MSD_NN012 & M3 & Antilope cervicapra & MSDI & MHar & 7 & -3.4 & -1.0 & -2.2 & -1.9 & 2.4 \\
\hline MSD_NN013 & M2 & Bos indicus & MSDI & MHar & 8 & -1.1 & 0.3 & -0.2 & -0.1 & 1.4 \\
\hline
\end{tabular}

respectively. However both species can consume both graze and browse as part of their diets. It may well be that with further isotopic analyses of sheep and goat which have been identified to species (possibly via the use of ZooMS) differences between these two species will be seen based upon their dietary preferences (although we note that such distinctions were not visible in the wild animal species sampled either). Our data from later time periods suggest that this sheep and goat management strategy changed over time, as the small number of Painted Grey Ware and Early Historic samples have diets dominated by $\mathrm{C}_{4}$ plants throughout the time of tooth formation, although with a sample size of three individuals, this conclusion must remain speculative. We also note that all three of these post-Indus samples are from Alamgirpur, and it may be that they represent a distinct local animal management tradition rather than a change through time. The single Mature Harappan sheep from Alamgirpur has carbon isotope values that are ambiguous in that they are relatively high but do show some variation.
The (bulk) carbon isotope values of pig/wild boar tooth enamel indicate a diet largely dependent upon $\mathrm{C}_{3}$ resources. The individual identified as domestic has a carbon isotope value very similar to that of three of the four wild pigs, whilst one of the wild pigs has a mixed $\mathrm{C}_{3}-\mathrm{C}_{4}$ diet, similar to other wild ruminants we have analysed.

The archaeobotanical evidence suggests that many plant species were grown at Indus sites, including wheat, barley and rice $\left(\mathrm{C}_{3}\right)$, as well as $\left(\mathrm{C}_{4}\right)$ millets. The $\mathrm{C}_{3}$ species were not being fed to cattle and buffalo in significant quantities at the analysed sites, although they may have been fed to sheep, goat and pig. While isotopic evidence from human remains is very scarce, data from Harappa (Kenoyer et al., 2013) suggest that human diets here were based upon $\mathrm{C}_{3}$ resources. If these human data from Harappa are representative of other areas of the Indus, it is possible that large grained, $C_{3}$ cereals were reserved for human consumption while small grained cereals (i.e. millets) were grown for forage, and consumed by humans only as a famine food.

In summary, these data suggest at least two and potentially three 


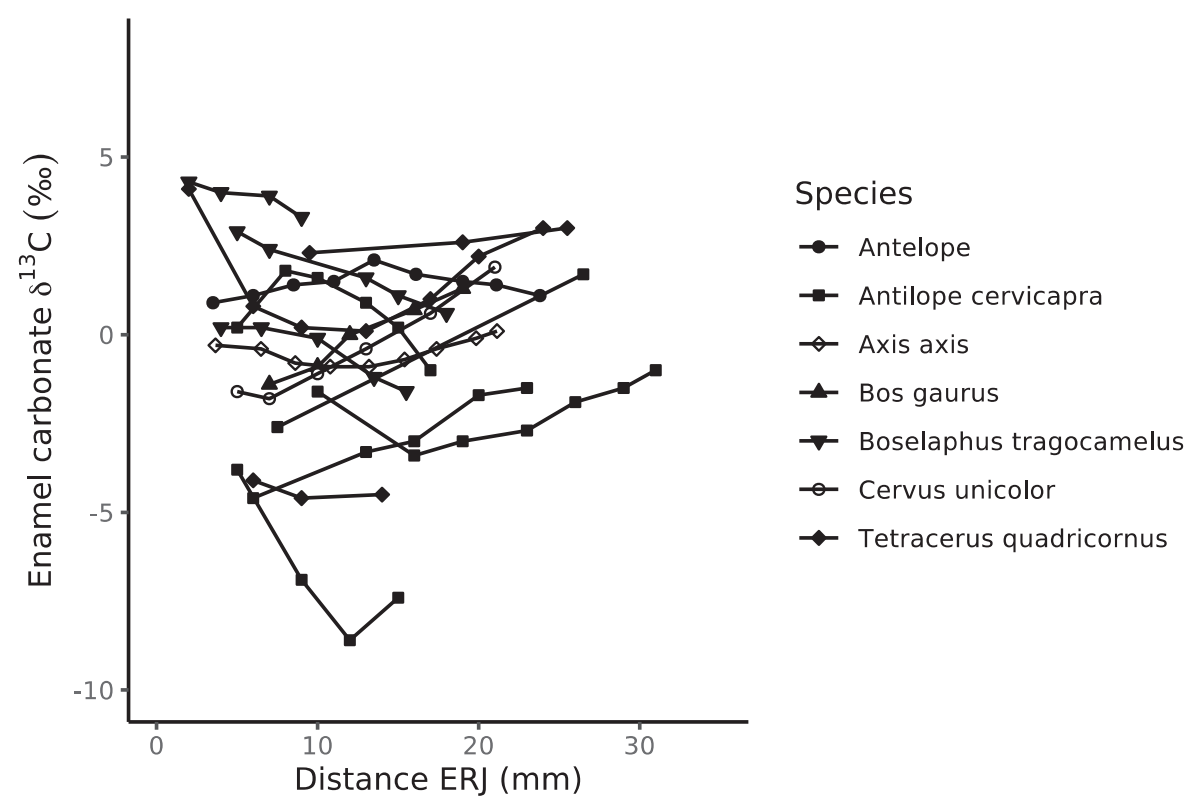

Fig. 3. Scatter plot showing enamel carbonate sequential intra-tooth carbon isotope results from wild animal species, plotted as a function of distance from the enamel root junction (ERJ).

different domestic animal diets during the Mature Harappan period: one for cattle and water buffalo who largely consumed $\mathrm{C}_{4}$ plants; another for sheep and goat who ate both $\mathrm{C}_{3}$ and $\mathrm{C}_{4}$ plants but in varying proportions throughout the year; and, potentially, a third for pigs who consumed largely $\mathrm{C}_{3}$ resources. The data from wild animals suggest that a free roaming animal could occupy a range of ecological niches, but generally the wild species' diets are most similar to those of the sheep and goat. It therefore seems reasonable to suggest that very different animal management strategies were practised for the three groups of domestic animals. In the case of the cows and water buffalo, whose access to food was possibly highly restricted by humans, it seems likely that these animals were kept close by, potentially within settlements,

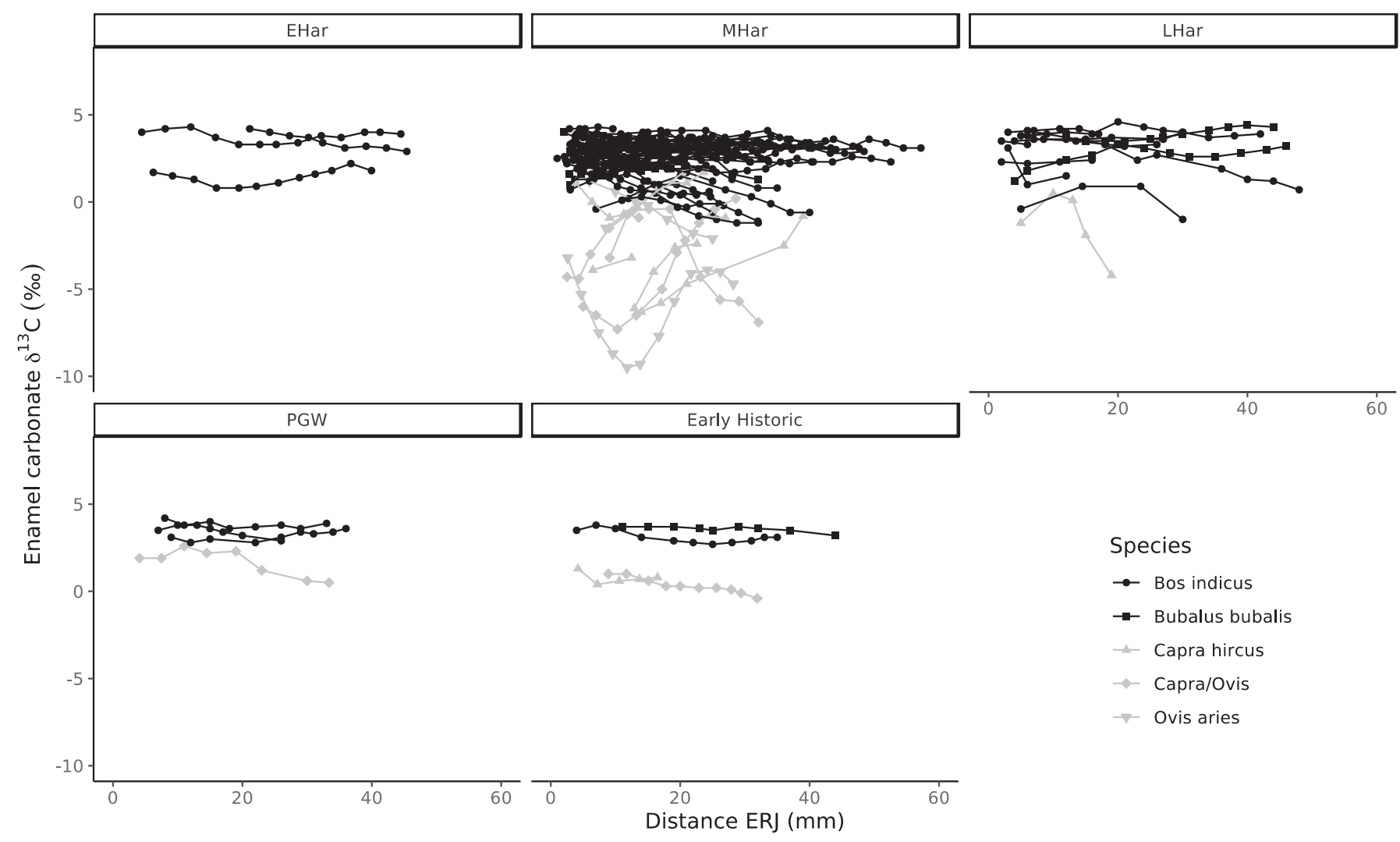

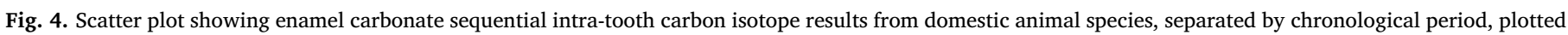

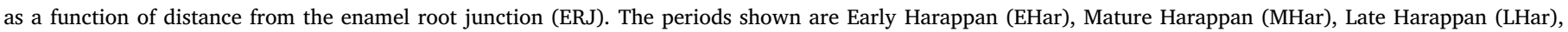
Painted Grey Ware (PGW) and Early Historic. 


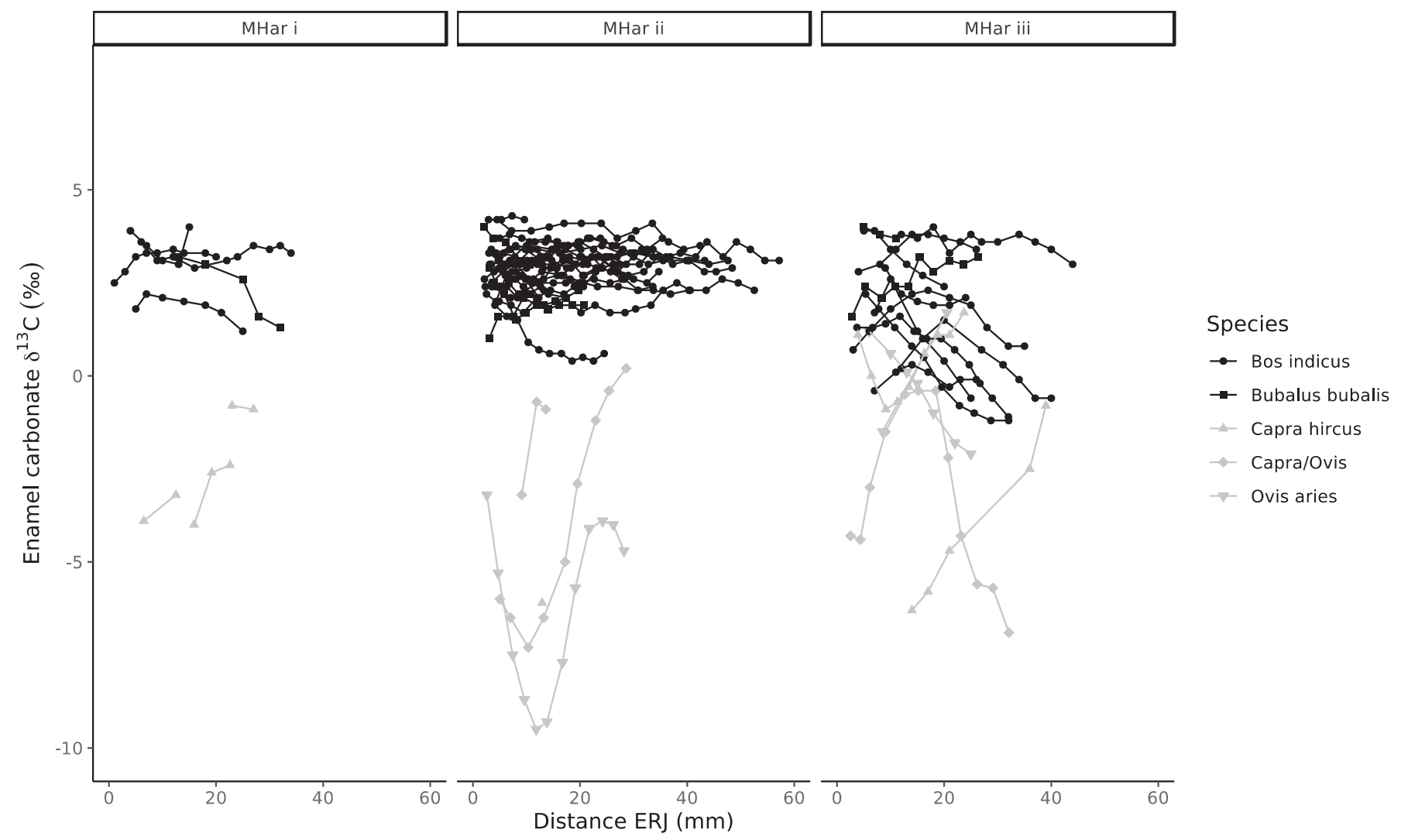

Fig. 5. Scatter plot showing enamel carbonate sequential intra-tooth carbon isotope results from Mature Harappan period domestic animal species, separated by chronological phase, plotted as a function of distance from the enamel root junction (ERJ).

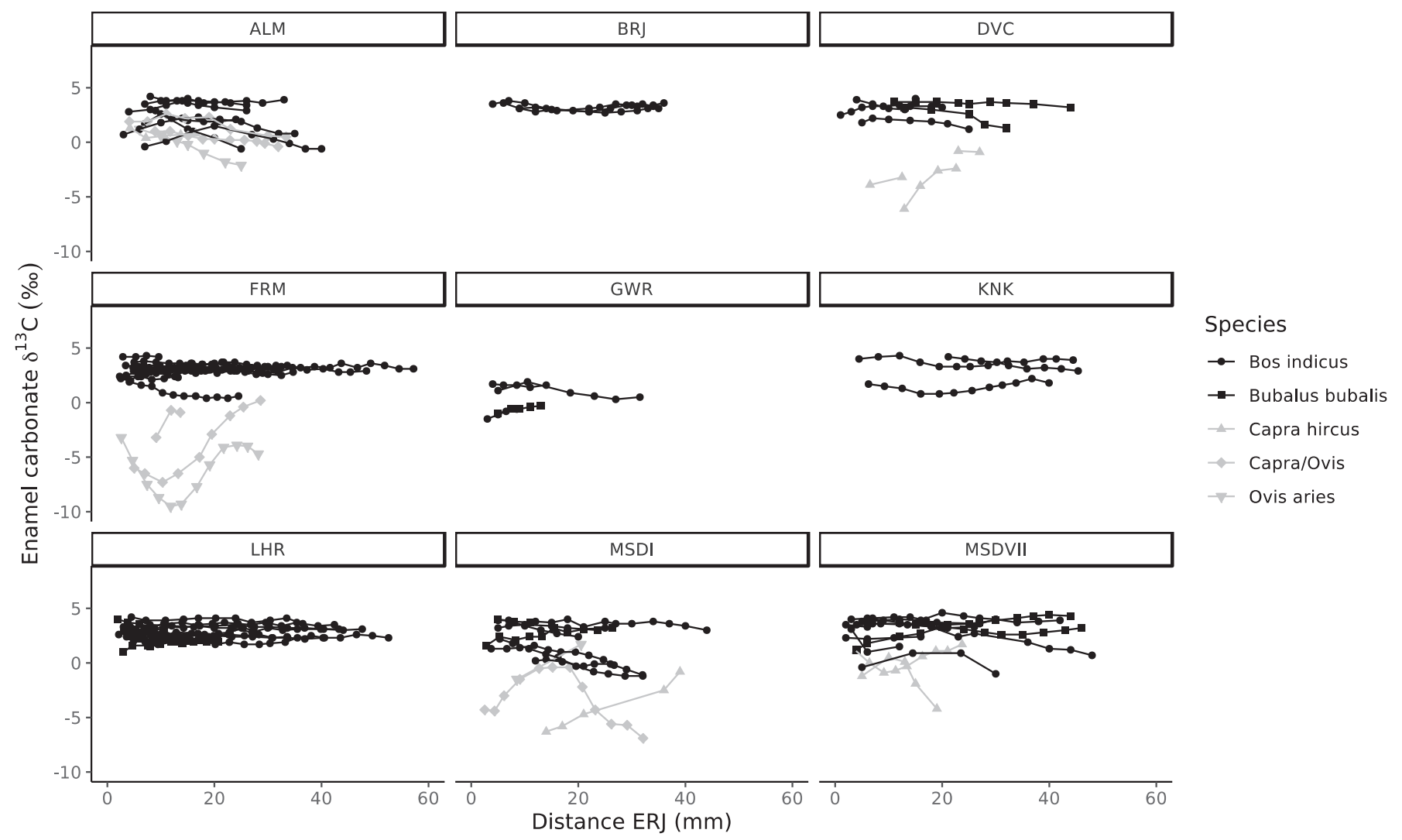

Fig. 6. Scatter plot showing enamel carbonate sequential intra-tooth carbon isotope results from domestic animal species, separated by site, plotted as a function of distance from the enamel root junction (ERJ). Site names and codes given in Table 1. 
and their mobility was restricted on a day-to-day basis. This reconstruction fits well with the use of these animals for traction, ploughing, transport and dairying, but does not preclude the possibility of long-distance movement and trade of animals. A far more mobile and less constrained management strategy is likely for sheep and goats, which probably roamed more freely in the landscape for at least part of the year. Again, this day-to-day mobility strategy does not preclude the possibility of long-distance trade in animals, nor did this mobility strategy necessarily involve flocks travelling long distances.

Testing these animal management strategies through the direct analysis of animal movement using strontium isotope analysis is likely to be difficult if sheep and goat were not moved very far on a day to day basis. If this were the case, the strontium isotope ratios of sheep and goat may well reflect a local signal, bearing in mind that the 'local' signal reflects geology and therefore might equate to a large area of the countryside. When one considers that long-distance movement of animals is to be expected within the Indus context, whether for agricultural or transportation purposes (there was certainly long-distance trade of other, non-perishable, raw materials and commodities; Kenoyer, 1998; Law, 2011; Wright, 2010), then it is likely that any local mobility signal will be insignificant compared to the isotopic variation caused by longdistance movement.

\subsection{Implications for separation of agricultural tasks during the Mature Harappan period}

How would such an animal management strategy have worked in practice during the Mature Harappan period? The scenario outlined above involves, for at least part of the year, cattle and water buffalo (and perhaps pigs) being kept close to home while the sheep and goat roamed the landscape. In practical terms, it is unlikely that one person would have been able to manage both of these groups of animals, let alone be able to grow crops as well. These data thus suggest a scenario whereby there were at least two people, or potentially two groups of people, who performed different agricultural tasks related to animals at Indus settlements. Many different ways of dividing tasks between people can be imagined, including but not limited to: different people within a household (children versus adults, males versus females, or simply based on personal preference); different households within a settlement with different agricultural specialisms; agriculturally specialised settlements; and two entirely different social groups - more mobile pastoralists concentrating on sheep and goat and who could also have grown less labour intensive crops (such as some species of millet), and settled mixed agriculturalists focusing on cattle and arable agriculture.

There are several ways that these separation of task scenarios can and should be tested. For example, if there were two groups of people living mobile and sedentary lifestyles, one would expect to find temporary settlements alongside permanent settlements. There is some evidence for this in Gujarat and Cholistan (Mughal, 1997; Rissman and Chitalwala, 1990). In Cholistan temporary camp sites are far more prevalent in the Hakra (i.e. pre-urban) and Late Harappan (i.e. posturban) periods than they were during the urban phase, though none of these sites has yet been excavated. If these two groups further differed in their agricultural strategies along the lines discussed above, one would expect that the sites occupied by pastoral populations would have more neonatal lamb and kid remains as opposed to neonatal calves, and vice versa for the permanent settlements. Further, in terms of arable production, while the mobile groups likely consumed grain, one would perhaps expect to find archaeobotanical evidence biased towards grain consumption at temporary settlements, and archaeobotanical evidence for grain production and consumption at permanent sites, although we note that pastoralists often grow less labour intensive crops. Further, if human remains were available for analysis, one might expect mobile pastoralists to have osteological and isotopic evidence for high protein diets and high habitual mobility relative to settled populations.

While a plausible scenario, the hypothesis that there could have been permanent settlements which specialised in different animals (regardless of any arable activities) can reasonably be discounted given the available zooarchaeological evidence. If this were the case, then one would expect the proportion of animal remains in Indus zooarchaeological assemblages to show more variation, that is one would expect some settlements to specialise in raising sheep and goats and therefore to have a very high proportion of sheep and goat remains. However, the available evidence indicates that cows and water buffalo dominate zooarchaeological assemblages across the Indus Civilisation. Nevertheless, a further examination of neonatal animal remains at Indus sites would be welcome to provide additional evidence for or against this conclusion.

Testing the hypothesis that different households within a permanent settlement raised different species of animals is likely to be difficult, and would rely on the archaeological visibility of the above criteria (i.e. zooarchaeological and archaeobotanical evidence) on a household level. The absence of evidence for different groups and for household specialisation, combined with positive zooarchaeological evidence for young sheep/goat and cattle/water buffalo would likely suggest division of labour on a household level, although determining which individuals performed which tasks would be extremely difficult and rely upon osteological (and potentially human isotopic) evidence.

\subsection{Adaptability, sustainability and resilience}

Regardless of how the various agricultural tasks were organised in practice, it seems that a Mature Harappan strategy that led to different animal diets was successful, in that the isotopic pattern holds across the sites analysed here, and those published from Gujarat. This intra- and inter-regional similarity suggests that this animal management strategy was adaptable to the range of environmental and social conditions represented by the sites presented here and published sites in Gujarat. This lack of variation is in direct contrast to the evidence from archaeobotany which suggests variation between regions in arable agricultural patterns (Petrie and Bates, 2017; Weber, 1999; Weber et al., 2010), as discussed above.

Considering the data diachronically, it is clear that the consumption of $\mathrm{C}_{4}$ plants by cattle and water buffalo was consistent through time from the Early Harappan through to the Early Historic period, at least at the sites analysed here. The implication is that $\mathrm{C}_{4}$ plants were readily available and/or easy to grow, easy to gather and/or harvest, and produced a large amount of plant matter that was not otherwise being used by humans. The long time-frame involved suggests that this strategy was sustainable for at least 2000 years. Furthermore, this strategy persisted across the development, floruit and decline of Indus urbanism and in spite of the climatic changes associated with the $4.2 \mathrm{ka}$ BP event and the subsequent period of unpredictable climate (Petrie et al., 2017). The persistence of this strategy suggests that it was resilient to acute challenges and sustainable over the long term.

Notably, our limited evidence suggests that the diet of sheep and goats did change through time, shifting from a less to a more managed or restricted food provision. Unfortunately, this assessment is hampered by the small sample sizes, and the fact that the three post-Indus sheep and goat all come from one site. It is therefore difficult to distinguish between a different animal management strategy at Alamgirpur and change through time. Given the consistency between the data from other sites, however, we tentatively suggest that change through time is the most likely of the two options. If this is the case, then this pattern would suggest that the Mature Harappan sheep and goat management strategy was less sustainable or less resilient than that of the cattle and water buffalo. One can speculate therefore that shifting sheep and goat diets towards $\mathrm{C}_{4}$ foods may have removed risks associated with declining rainfall, as $\mathrm{C}_{4}$ plant species tend to require less water and are thus more sustainable than $\mathrm{C}_{3}$ plants when water is limited. One can 
also imagine a potentially related scenario whereby $C_{3}$ plant foods became less available through time, perhaps due to changing climate or changing social or environmental circumstances leading to a decline in available arable land. In this scenario, sheep and goat may have been competing with humans for $\mathrm{C}_{3}$ plant foods and/or farmland, and sheep and goat diets were deliberately shifted towards $\mathrm{C}_{4}$ plants, either to ensure that people had better access to $C_{3}$ plant foods like wheat and rice or because $\mathrm{C}_{4}$ plant foods became more abundant, which is suggested by the available archaeobotanical evidence from the same sites (Bates, 2016; Bates et al., 2017, 2018; Petrie and Bates, 2017). An alternative suggestion might be that, for some reason, the mobility patterns of sheep and goat was reduced and therefore more direct foddering was necessary. Ultimately, confirming that such a change took place, and understanding why it occurred, will require much more research, particularly on sites post-dating the Indus period.

\section{Conclusions}

This study has shown that the dietary evidence for the animal management strategies employed in nine settlements in the north of the Indus zone were (isotopically) very similar to those from two Indus period sites in Gujarat. In the Mature Harappan period, cattle and water buffalo consumed high proportions of $\mathrm{C}_{4}$ plants throughout the year, sheep and goat ate a diet containing both $\mathrm{C}_{3}$ and $\mathrm{C}_{4}$ species in variable proportions, while pigs consumed a diet largely based on $\mathrm{C}_{3}$ foodstuffs. This pattern is also consistent across sites in different parts of northwest India, suggesting that it was adaptable to a range of environmental conditions. The high consumption of $\mathrm{C}_{4}$ foodstuffs by cows and water buffalos is also consistent through time, suggesting that it was sustainable as well as resilient to adversity, and there are hints that this diet was adopted for sheep and goat in later periods. The evidence for different animal diets during the Indus urban period has implications for the management of herds and the organisation of society. There appears to be a clear separation of tasks within individual settlements and communities, though further research is needed to understand if the implied separation of tasks was organised on a household, settlement or population level.

Supplementary data to this article can be found online at https:// doi.org/10.1016/j.ara.2020.100212.

\section{Declaration of competing interest}

The authors declare no competing interests.

\section{Acknowledgements}

We would like to thank Catherine Kneale and James Rolfe (University of Cambridge) for their assistance with the mass spectrometry. We also thank the Archaeological Survey of India, Government of India, who gave permission to export the samples to Cambridge for study, as well as to Banaras Hindu University (eight sites) and Deccan College (one site) who supplied the samples. This research was funded by the European Research Council (ERC) under the Horizon 2020 research and innovation programme (TwoRains project: grant agreement number 648609) and the FP7 programme (Food Globalization in Prehistory project: grant number GA249642). P.J. Jones' overall doctoral study was funded by the Rae and Edith Bennett Travelling Scholarship.

\section{Author statement}

EL, PJJ and CP conceptualised the study, EL carried out the formal analysis, EL, PJJ, MTD, ES, JM carried out the investigation, PPJ, VS, RNS and TCOC provided resources, MKJ and CAP engaged in funding acquisition, RNS, MKJ and CAP provided project administration, MKJ,
TCOC and CAP provided supervision, EL and CAP wrote the original draft, and EL, PJJ, PPJ, MTD, ES, JM, RNS, MKJ, TCOC and CAP were involved with review and editing.

\section{References}

Balasse, M., 2002. Reconstructing dietary and environmental history from enamel isotopic analysis: time resolution of intra-tooth sequential sampling. Int. J. Osteoarchaeol. 12, 155-165.

Balasse, M., 2003. Potential biases in sampling design and interpretation of intra-tooth isotope analysis. Int. J. Osteoarchaeol. 13, 3-10.

Balasse, M., Ambrose, S.H., Smith, A.B., Price, T.D., 2002. The seasonal mobility model for prehistoric herders in the south-western cape of South Africa assessed by isotopic analysis of sheep tooth enamel. J. Archaeol. Sci. 29 (9), 917-932.

Bates, J., 2016. Social Organisation and Change in Bronze Age South Asia: A Multi-Proxy Approach to Urbanisation, Deurbanisation and Village Life through Phytolith and Macrobotanical Analysis. PhD thesis submitted to the Department of Archaeology. University of Cambridge.

Bates, J., Singh, R.N., Petrie, C.A., 2017. Exploring Indus crop processing: combining phytolith and macrobotanical analyses to consider the organisation of agriculture in Northwest India c. 3200-1500 bc. Veg. Hist. Archaeobotany 26, 25-41.

Bates, J., Petrie, C., Singh, R., 2018. Cereals, calories and change: exploring approaches to quantification in Indus archaeobotany. Archaeol. Anthropol. Sci. 10, 1703-1716.

Beneke, N., Neef, R., 2005. In: Franke-Vogt, U., Weisshaar, H.J. (Eds.), Faunal and Plant Remains from Sohr Damb/Nal: A Prehistoric Site (c. 3500-2000 BC) in Central Balochistan (Pakistan). South Asian Archaeology 2003 Aachen, pp. 81-91.

Brown, W.A.B., Christofferson, P.V., Massler, M., Weiss, M.B., 1960. Postnatal tooth development in cattle. Am. J. Vet. Res. 21, 7-34.

Cadwallader, L., Beresford-Jones, D.G., Whaley, O.Q., O'Connell, T.C., 2012. The signs of maize? A reconsideration of what $\delta^{13} \mathrm{C}$ values say about palaeodiet in the Andean region. Hum. Ecol. 40, 487-509.

Chakraborty, K.S., Chakraborty, S., le Roux, P., Miller, H.M.-L., Shirvalkar, P., Rawat, Y., 2018. Enamel isotopic data from the domesticated animals at Kotada Bhadli, Gujarat, reveals specialized animal husbandry during the Indus Civilization. J. Archaeol. Sci. Rep. 21, 183-199.

Chase, B., 2010. Social change at the Harappan settlement of Gola Dhoro: a reading from animal bones. Antiqity 84, 528-543.

Chase, B., 2012. Crafting Harappan cuisine on the Saurashtran frontier of the Indus Civilization. In: Gaff, S., Rodriguez-Alegria, E. (Eds.), The Menial Art of Cooking: Archaeological Studies of Cooking and Food Preparation. University Press of Colorado, Colorado.

Chase, B., 2014. On the pastoral economies of Harappan Gujarat: faunal analyses at Shikarpur in context Heritage. J. Multidiscip. Stud. Archaeol. 2, 1-22.

Chase, B., Meiggs, D., Ajithprasad, P., Slater, P.A., 2014. Pastoral land-use of the Indus Civilization in Gujarat: faunal analyses and biogenic isotopes at Bagasra. J. Archaeol. Sci. 50, 1-15.

Chase, B., Meiggs, D., Ajithprasad, P., 2020. Pastoralism, climate change, and the transformation of the Indus Civilization in Gujarat: faunal analyses and biogenic isotopes. J. Anthropol. Archaeol. 59, 101173.

Coplen, T.B., 1995. New IUPAC guidelines for the reporting of stable hydrogen, carbon and oxygen isotope-ratio data. Journal of Research of the National Institutes of Standards and Technology 100, 285.

Craig, H., 1957. Isotopic standards for carbon and oxygen and correction factors for massspectromic analysis of carbon dioxide. Geochim Cosmochim Acta 12 (1-2), 133-149.

Deshpande-Mukherjee, A., Sen, A., Rao, L.S., Weissbrod, 2007. Human-animal interactions during the Harappan period in the Ghaggar Region of Northern India: Insights from Bhirrana. In: Maron, N., Yeshrun, R., Bar-Oz, G. (Eds.), Bones and Identity: Zooarchaeological Approaches to Reconstructing Social and Cultural Landscapes in Southwest Asia. Oxbow Books, Oxford.

Dixit, Y., Tandon, S.K., 2016. Hydroclimatic variability on the Indian subcontinent in the past millennium: review and assessment. Earth Sci. Rev. 161, 1-15.

Dixit, Y., Hodell, D.A., Petrie, C.A., 2014. Abrupt weakening of the summer monsoon in Northwest India 5100 yr ago. Geology 42 (4), 339-342.

Dixit, Y., Hodell, D.A., Giesche, A., Tandon, S.K., Gázquez, F., Saini, H.S., Skinner, L.C., Mujtaba, S.A.I., Pawar, V., Singh, R.N., Petrie, C.A., 2018. Intensified summer monsoon and the urbanization of Indus Civilization in Northwest India. Sci. Rep. 8, 4225 .

Ehleringer, J.R., Monson, R.K., 1993. Evolutionary and ecological aspects of photosynthetic pathway variation. Annu. Rev. Evol. Syst. 24, 411-439.

Fairservis, W.A., 1961. The Harappan Civilization-new evidence and more theory. In: American Museum Novitates No. 2055. American Museum of Natural History, New York.

Feranec, R.S., Hadley, E.A., Paytan, A., 2009. Stable isotopes reveal seaonal competition for resources between late Pleistocene bison (Bison) and horse (Equus) from rancho La Brea, southern California. Palaeogeogr. Palaeocliat. Palaeoecol. 271, 153-160.

Giesche, A., Staubwasser, M., Petrie, C.A., Hodell, D.A., 2019. Indian winter and summer monsoon strength over the $4.2 \mathrm{kaBP}$ event in foraminifer isotope records from the Indus River delta in the Arabian Sea. Clim. Past 15, 73-90.

Guha, S., 1994. Recognizing 'Harappan': a critical review of the position of huntergatherers within Harappan society. South Asian Stud. 10, 91-97.

Heaton, T.H.E., 1999. Spatial, species, and temporal variations in the 13C/12C ratios of C3 plants: implications for paleodiet studies. J. Archaeol. Sci. 26, 637-649.

Joglekar, P., Sharada, C.V., Abhayan, G.S., 2013. Faunal diversity during the Harappan period in Haryana: a review. Herit. J. Multidiscip. Stud. Archaeol. 1, 262-287.

Joglekar, P.P., Singh, R.N., Petrie, C.A., 2016. A preliminary report of animal remains from Bhimwada Jodha (Masudpur VII), Haryana. Bharati 39, 1-9.

Kenoyer, J.M., 1991. Urban process in the Indus tradition: a preliminary model from Harappa. In: Meadow, R.H. (Ed.), Harappa Excavations 1986-1990. Prehistory Press, 
Madison, pp. 71-80.

Kenoyer, J.M., 1998. Ancient Cities of the Indus Valley Civilization. Oxford University Press, Oxford.

Kenoyer, J.M., 2008. Indus urbanism: new perspectives in its origin and character. In: Marcus, J., Sabloff, J.A. (Eds.), The Ancient City: New Perspectives in the Old and New World. SAR, Santa Fe, NM, pp. 85-109.

Kenoyer, J.M., Price, T.C., Burton, J.H., 2013. A new approach to tracking connections between the Indus Valley and Mesopotamia: initial results of strontium isotope analyses from Harappa and Ur. J. Archaeol. Sci. 40, 2286-2297.

Law, R.W., 2011. Inter-Regional Interaction and Urbanism in the Ancient Indus Valley: A Geological Provenience Study of Harappa's Rock and Mineral Assemblage (Linguistics, Archaeology and the Human Past Occasional Paper, Vol. 11). Research Institute for Humanity and Nature, Kyoto.

Lightfoot, E., Liu, X., Jones, P.J., 2018. A world of C4 pathways: on the use of $813 \mathrm{C}$ values to identify the consumption of C4 plants in the archaeological record. In: Lightfoot, E., Fuller, D.Q., Liu, X. (Eds.), Far from the Hearth: Essays in Honour of Martin K Jones. McDonald Institute Monographs, Cambridge.

Madella, M., 2014. Of crops and food: a social perspective on rice in the Indus Civilization. In: Madella, M., Lancelotti, C., Savard, M. (Eds.), Ancient Plants and People: Contemporary Trends in Archaeology. University of Arizona Press, Tuscon, pp. 218-236.

Makarewicz, C.A., Pederzani, S., 2017. Oxygen $\left(\delta^{18} \mathrm{O}\right)$ and carbon $\left(\delta^{13} \mathrm{C}\right)$ isotopic distinction in sequentially sampled tooth enamel of co-localized wild and domestic caprines: complications to establishing seasonality and mobility in herbivores. Palaeogeogr. Palaeoclimatol. Palaeoecol. 485, 1-15.

Marshall, J., 1931. Mohenjo-Daro and the Indus Civilization. Vol. I-III Arthur Prob, London.

Meadow, R.H., 1979. Prehistoric subsistence at Balakot: initial consideration of the faunal remains. In: Taddei, M. (Ed.), South Asian Archaeology 1977. Istitutio Universitario Orientale, Naples, pp. 275-315.

Meadow, R.H., 1991. Faunal remains and urbanism at Harappa. In: Meadow, R.H. (Ed.), Harappa Excavations 1986-1990: A Multidisciplinary Approach to Third Millennium. Urbanism Prehistory Press, Madison, Wisconsin.

Meadow, R.H., 1996. The origins and spread of agriculture and pastoralism in northwestern South Asia. In: Harris, D.R. (Ed.), The Origins and Spread of Agriculture and Pastoralism in Eurasia. Institute of Archaeology, University College London, London, pp. 390-412.

Meadow, R.H., Kenoyer, J.M., 1997. Excavations at Harappa 1994-1995: new perspectives on the Indus script, craft activities and city organization. In: Allchin, B., Allchin, F.R. (Eds.), South Asian Archaeology 1995. Oxford \& IBH, New Delhi, pp. 139-172.

Meadow, R.H., Patel, A., 2003. Prehistoric pastoralism in northwest south Asia from the Neolithic through to the Harappan Period. In: Weber, S., Belcher, W.R. (Eds.), Indus Enthnobiology, pp. 65-94 Lanham, Lexington.

Miller, L.J., 2004. Urban Economies in Early States: The Secondary Products Revolution in the Indus Civilization. PhD thesis submitted to the Department of Anthropology. New York University.

Misra, P., Tandon, S.K., Sinha, R., 2019. Holocene climate records from lake sediments in India: assessment of coherence across climate zones. Earth-Sci. Rev. 190, 370-397.

Mughal, M.R., 1970. The Early Harappan Period in the Greater Indus Valley and Northern Baluchistan (c. 3000-2400BC). PhD thesis submitted to University of Pennsylvania.

Mughal, M.R., 1997. Ancient Cholistan: Archaeology and Architecture. Ferozsons, Rawalpindi.

O'Leary, M.H., 1988. Carbon isotopes in photosynthesis. BioScience 38, 328-336.

Parikh, D., Petrie, C.A., 2019. 'We are the inheritors of a rural civilisation': rural complexity and the ceramic economy in the Indus Civilisation in northwest India. World Archaeol. 50 (2), 1-21.

Passey, B.H., Robinson, T.F., Ayliffe, L.K., Cerling, T.E., Sponheimer, M., Dearing, M.D., Roeder, B.L., Ehleringer, J.R., 2005. Carbon isotope fractionation between diet, breath $\mathrm{CO}_{2}$ and bioapatite in different mammals. J. Archaeol. Sci. 32, 1459-1470.

Patel, A., 1997. The pastoral economy of Dholavira: a first look at animals and urban life in third millennium Kutch. In: Allchin, R., Allchin, B. (Eds.), South Asian Archaeology 1995. Vol. 1. The Ancient India and Iran Trust, Cambridge, pp. 101-113.

Patel, A., 2015. Analysis of faunal remains from the excavations at Dholavira (district Kutch, Gujarat). In: Bisht, R.S. (Ed.), Excavations at Dholavira 1989-90 to 2004-2005. Archaeological Survey of India, New Delhi, pp. 839-869.

Petrie, C.A., 2013. South Asia. In: Clark, P. (Ed.), The Oxford Handbook of Cities in World History. Oxford University Press, Oxford, pp. 83-104.

Petrie, C.A., 2017. Crisis, what crisis? Adaptation, resilience and transformation in the Indus Civilisation. In: Cunningham, T., Driessen, J. (Eds.), Crisis to Collapse: The Archaeology of Social Breakdown. Aegis Publications, UC Louvain, pp. 43-64.

Petrie, C.A., Bates, J., 2017. Multi-cropping', intercropping and adaptation to variable environments in the Indus Civilisation. J. World Prehist. 30, 81-130.

Petrie, C.A., Bates, J., Higham, T., Singh, R.N., 2016. Feeding ancient cities in South Asia: dating the adoption of rice, millet and tropical pulses in the Indus civilisation. Antiquity 90 (354), 1489-1504.

Petrie, C.A., Singh, R.N., Bates, J., Dixit, Y., French, C.A.I., Hodell, D., Jones, P.J., Lancelotti, C., Lynam, F., Neogi, S., Pandey, A.K., Parikh, D., Pawar, V., Redhouse, D.I., Singh, D.P., 2017. Adaptation to variable environments, resilience to climate change: investigating Land, Water and Settlement in northwest India. Curr. Anthropol. 58 (1), 1-30.

Petrie, C.A., Parikh, D., Green, A.S., Bates, J., 2018. Looking beneath the veneer: thoughts about environmental and cultural diversity in the Indus Civilisation. In: Frenez, D., Jamison, G., Law, R., Vidale, M., Meadow, R.H. (Eds.), Walking with the Unicorn. Social Organization and Material Culture in Ancient South Asia. Archaeopress, Oxford, pp. 455-476.
Petrie, C.A., Singh, R.N., Alam, A., Bates, J., Ceccarelli, A., Chakraborty, S., Chakradhari, S., Chowdhary, A., Dixit, Y., French, C.A.I., Gieshe, A., Green, A.S., Green, L.M., Lightfoot, E., Pandey, A.K., Ranjan, A., Redhouse, D.I., Singh, D.P., Singh, U., Suryanarayan, A., Üstünkaya, M.C., Walker, J.R., 2019. Living in the hinterland: progress of the TwoRains project in 2016 and 2018. In: Filigenci, A. (Ed.), EASAA 2018 ISMEO, Naples. in press a (submitted).

Petrie, C.A., Singh, R.N., Alam, A., Bates, J., Baudouin, J.P., Ceccarelli, A., Chakraborty, S., Chakradhari, S., Chowdhary, A., Dixit, Y., French, C.A.I., Garcia-Molsosa, A., Gieshe, A., Green, A.S., Green, L.M., Hodell, D., Joglekar, P.P., Jones, P.J., Lancelotti, C., Lightfoot, E., Neogi, S., O'Connell, T.C., Orengo, H.A., Pandey, A.K., Parikh, D., Pathak, Pawar V., Ranjan, A., Redhouse, D.I., Saraswat, K.S., Singh, D.P., Singh, U., Suryanarayan, A., Üstünkaya, M.C., Walker, J.R., 2020. Rethinking human and environment relationships in ancient northwest India: insights from the Land, Water and Settlement and TwoRains projects. In: Ancient India (New Series) 5. Recent Advances in Harappan Archaeology in press (submitted 2020).

Pokharia, A.K., Kharakwal, J.S., Rawat, R.S., Osada, T., Mautiyal, C.M., Srivastava, A. 2011. Archaeobotany and archaeology at Kanmer, a Harappan site in Kachchh, Gujarat: evidence for adaptation in response to climatic variability. Curr. Sci. 100 (12), 1833-1846.

Possehl, G.L., 1977. The end of a state and a century of a tradition. In: Fox, R.G. (Ed.), Realm and Religion in Traditional India. Carolina Academy Press, Durham.

Possehl, G.L., 2002. The Indus Civilization: A Contemporary Perspective. AltaMira Press, Walnut Creek.

R Core Team, 2017. R: A Language and Environment for Statistical Computing. R Foundation for Statistical Computing, Vienna, Austria.

Reddy, C.N., 2003. Discerning Palates of the Past: An Ethnoarchaeological Study of Crop Cultivation and Plant Usage in India. International Monographs on Prehistory, Ann Arbour, Michigan, USA.

Rissman, P.C., Chitalwala, Y.M., 1990. Harappan Civilization and Oriyo Timbo. Oxford and IBH Publishing, New Delhi.

Rizvi, U.Z., 2007. Configuring the Space in Between: Redefining the Ganeshwar Jodhpura Cultural Complex in Northeastern Rajasthan, India. PhD thesis submitted to the University of Pennsylvania.

Rizvi, U.Z., 2013. Crafting communities and producing places: copper, settlement patterns, and social identity in the Ganeshwar Jodhpura Cultural Complex, Rajasthan, India. In: Abraham, S.A., Gullapalli, P., Raczek, T., Rizvi, U.Z. (Eds.), Connections and Complexity: New Approaches to the Archaeology of South Asia. Left Coast Press, Walnut Creek, pp. 315-340.

Roux, V., Courty, M.-A., 1998. Identification of wheel-fashioning methods: technological analysis of 4th-3rd millennium BC oriental ceramics. J. Archaeol. Sci. 25, 747-763.

Sharada, C.V., 2018. A Study of Animal Utilization Strategies From Early to Late Harappan Periods in Haryana. South Asian Archaeology Series 3 Research group for South Asian Archaeology Archaeological Research Institute Kansai University, Kansai.

Shinde, V., Osada, T., Kumar, M., 2011. Excavations at Farmana, District Rohtak, Haryana, India 2006-2008 Kyoto. Indus Project, Research Institute for Humanity and Nature, Japan.

Shoko, C., Mutanga, O., Dube, T., 2016. Progress in remote sensing of C3 and C4 grass species aboveground biomass over time and space. ISPRS J. Photogramm. Remote Sens. 120, 13-24.

Singh, R.N., Pandey, A.K., Singh, D.P., Alam, A., 2019. Report on the ceramic assemblages of Ganeshwar, Sikar, Rajasthan. Indian J. Archaeol. 4 (1), 9-85.

Sinopoli, C.M., 2015. Ancient south Asian cities in their regions. In: Yoffee, N. (Ed.), The Cambridge World History III: Early Cities in Comparative Perspective, 4000 BCE-1200 CE. Cambridge University Press, Cambridge, pp. 319-342.

Tengberg, M., 1999. Crop husbandry at Miri Qalat, Makran, SW Pakistan (4000-2000 B.C.). Veg. Hist. Archaeobotany 8, 3-12.

Thomas, P.K., 2002. Investigations into the Archaeofauna of Harappan Sites in Western India. In: Settar, S., Korisettar, E. (Eds.), Indian Archaeology in Retrospect, Vol II, Protohistory, Archaeology of the Harappan Civilization. ICHR and Manohar, New Delhi, pp. 409-420.

Üstünkaya, M.C., Wright, N., Singh, R.N., Petrie, C.A., 2020. Adaptation to diverse en vironments: resilience through agroforestry and seasonality in the face of climate adversity. In: Vegetation History and Archaeobotany, in prep.

Varma, S., 1991. Villages abandoned: the case for mobile pastoralism in post-Harappan Gujarat. Stud. Hist. 7, 279-300.

Vishnu-Mittre, Sacithri, R., 1982. In: Possehl, G.L. (Ed.), Food Economy of the Harappans. Harappan Civilization, New Delhi.

Vogel, J.C., Van der Merwe, N.J., 1977. Isotopic evidence for early maize cultivation in New-York State. Am. Antiq. 42 (2), 238-242.

Weber, S.A., 1991. Plants and Harappan Subsistence: An Example of Stability and Change from Rojdi. Oxford and IBH, New Delhi.

Weber, S.A., 1999. Seeds of urbanism: palaeoethnobotany and the Indus Civilisation. Antiquity 73, 813-826.

Weber, S.A., 2003. Archaeobotany at Harappa: indications for change. In: Weber, S.A. Belcher, W.R. (Eds.), Indus Ethnobiology. Lexington Books, Lanham, pp. 175-198.

Weber, S.A., Kashyap, A., Harriman, D., 2010. Does size matter: the role and significance of cereal grains in the Indus civilization. Archaeol. Anthropol. Sci. 2, 35-43.

Weinreb, M.M., Sharav, Y., 1964. Tooth development in sheep. Am. J. Vet. Res. 25, 891-908.

Wickham, H., 2016. ggplot2: Elegant Graphics for Data Analysis. Springer-Verlag, New York.

Wright, R.P., 2010. The Ancient Indus Urbanism, Economy, and Society. Cambridge University Press, Cambridge. 